\title{
Review \\ Proteomics and Post-Translational Modifications of Starch Biosynthesis-Related Proteins in Developing Seeds of Rice
}

\author{
Piengtawan Tappiban ${ }^{1}$, Yining Ying ${ }^{1}$, Feifei $\mathrm{Xu}^{1}$ and Jinsong Bao ${ }^{1,2, *(1)}$ \\ 1 Key Laboratory of Nuclear Agricultural Sciences of Ministry of Agriculture and Zhejiang Province, \\ Institute of Nuclear Agricultural Sciences, College of Agriculture and Biotechnology, Zhejiang University, \\ Zijingang Campus, Hangzhou 310058, China; Piengtawan.tap@hotmail.com (P.T.); \\ ying_erin@163.com (Y.Y.); xuxufei@zju.edu.cn (F.X.) \\ 2 Hainan Institute of Zhejiang University, Yazhou Bay Science and Technology City, Yazhou District, \\ Sanya 572025, China \\ * Correspondence: jsbao@zju.edu.cn; Tel.: +86-571-86971932
}

Citation: Tappiban, P.; Ying, Y.; Xu,

F.; Bao, J. Proteomics and

Post-Translational Modifications of Starch Biosynthesis-Related Proteins in Developing Seeds of Rice. Int. J. Mol. Sci. 2021, 22, 5901. https:// doi.org/10.3390/ijms22115901

Academic Editor: Sixue Chen

Received: 13 April 2021

Accepted: 28 May 2021

Published: 31 May 2021

Publisher's Note: MDPI stays neutral with regard to jurisdictional claims in published maps and institutional affiliations.

Copyright: (c) 2021 by the authors. Licensee MDPI, Basel, Switzerland. This article is an open access article distributed under the terms and conditions of the Creative Commons Attribution (CC BY) license (https:/ / creativecommons.org/licenses/by/ $4.0 /)$.
Abstract: Rice (Oryza sativa L.) is a foremost staple food for approximately half the world's population. The components of rice starch, amylose, and amylopectin are synthesized by a series of enzymes, which are responsible for rice starch properties and functionality, and then affect rice cooking and eating quality. Recently, proteomics technology has been applied to the establishment of the differentially expressed starch biosynthesis-related proteins and the identification of posttranslational modifications (PTMs) target starch biosynthesis proteins as well. It is necessary to summarize the recent studies in proteomics and PTMs in rice endosperm to deepen our understanding of starch biosynthesis protein expression and regulation, which will provide useful information to rice breeding programs and industrial starch applications. The review provides a comprehensive summary of proteins and PTMs involved in starch biosynthesis based on proteomic studies of rice developing seeds. Starch biosynthesis proteins in rice seeds were differentially expressed in the developing seeds at different developmental stages. All the proteins involving in starch biosynthesis were identified using proteomics methods. Most starch biosynthesis-related proteins are basically increased at 6-20 days after flowering (DAF) and decreased upon the high-temperature conditions. A total of 10, $14,2,17$, and 7 starch biosynthesis related proteins were identified to be targeted by phosphorylation, lysine acetylation, succinylation, lysine 2-hydroxyisobutyrylation, and malonylation, respectively. The phosphoglucomutase is commonly targeted by five PTMs types. Research on the function of phosphorylation in multiple enzyme complex formation in endosperm starch biosynthesis is underway, while the functions of other PTMs in starch biosynthesis are necessary to be conducted in the near future.

Keywords: rice; starch biosynthesis; proteomics; posttranslational modification; starch functionality; cooking and eating quality

\section{Introduction}

Rice (Oryza sativa L.) is one of the most consumed cereal grains for half of the world's population and ranks as the third-largest crop, after sugarcane and maize [1,2]. The production quantity of rice was an estimated 214.08 million tonnes reported in 2018 [1], of which China, India, and Indonesia were the top-three highest production countries (Figure 1). Cultivated rice consists of two subspecies, O. sativa japonica and $O$. sativa indica $[3,4]$, which are highly distinct in terms of geographical distribution, visible morphological traits [5], and physiological characteristics (e.g., biotic and abiotic stress responses, cold tolerance, and seed quality) [6]. 


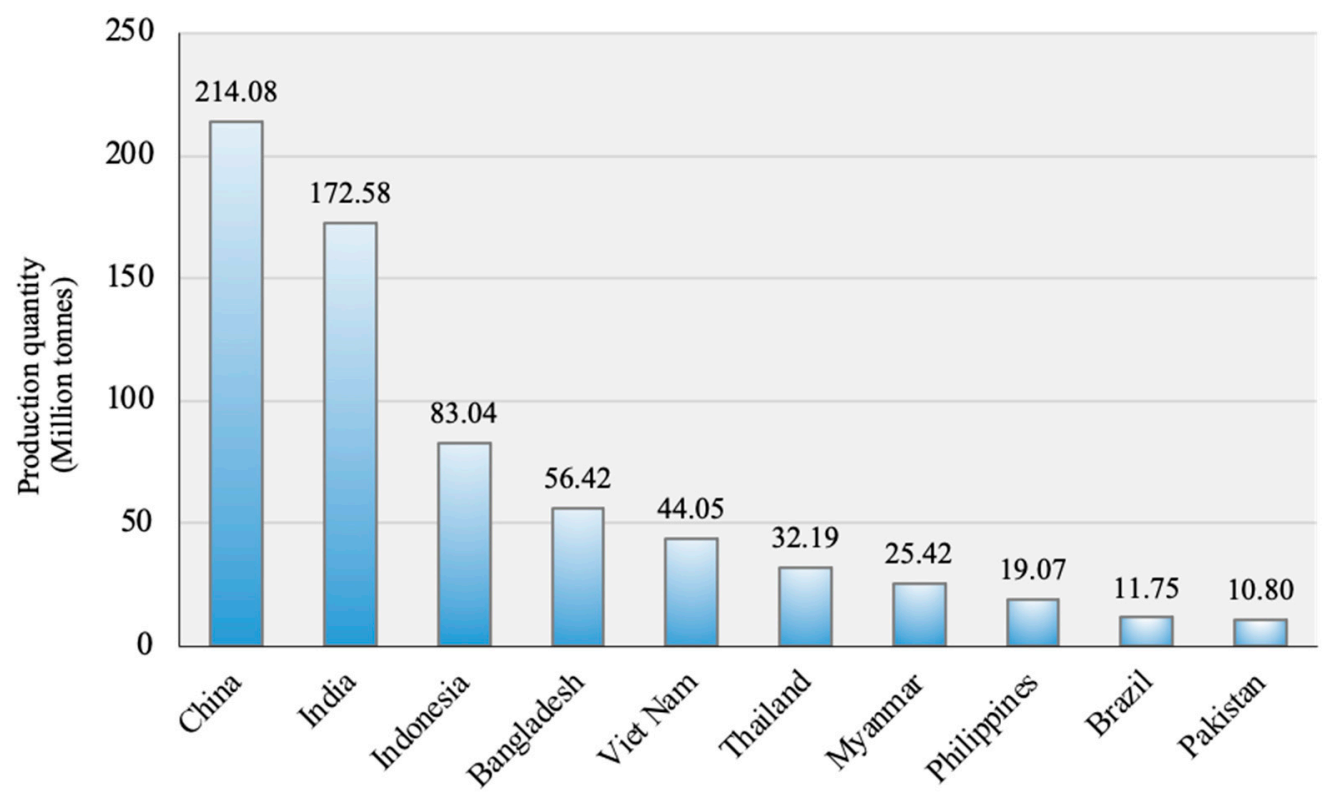

Figure 1. Production quantity of rice in 2018 from the top 10 countries based on FAOSTAT [1].

Rice seed consists of a minuscule embryo containing most of the genetic information and a relatively large endosperm containing most of the nutrient storage [7]. In mature rice endosperm, starch is a primary component with $80-90 \%$ of the total dry weight [8] and somewhat considered as a complex carbohydrate including amylose and amylopectin, which are synthesized and packed to form a large semicrystalline granule in amyloplasts through a large suite of enzyme activities [9]. Amylose is a linear chain made up of $\alpha-1,4$ glycosidic linked glucose molecules with very few $\alpha-1,6$ branches, whereas amylopectin, the main component of starch granule, is a highly branched chain of glucose units joined by both $\alpha-1,4$ and $\alpha-1,6$ glycosidic bonds [9-11]. Starch from different plant origins varies in its physicochemical properties due to the ratio of amylose and amylopectin and differences in branching density of semicrystalline structure [12]. Besides starch properties and functionalities, most studies of rice endosperm have been focused on starch biosynthesis protein expression and regulation [13-15]. Four main classes of starch biosynthesis enzymes including ADP-glucose pyrophosphorylase (AGPase), starch synthase (SS), starch branching enzyme (BE), and starch debranching enzyme (DBE) are presented in rice developing seeds $[9,10,16]$.

Proteomics has become an important tool to study the dynamic and diverse biological processes and analyze expression patterns, variation, function, and interaction of proteins at a given time, in a particular tissue, or among different treatments of biotic and abiotic stresses in plants [16-19]. Using two-dimensional gel electrophoresis (2-DE)-based protein identification method equipped with mass spectrometric techniques, the profile of entire protein expression can be rapidly generated with highly reproducible $[17,20]$, allowing for selection of the reasonable gene(s), which is possibly involved in regulatory mechanisms underlying starch biosynthesis $[13,21,22]$. In the last two decades, proteomic analyses of rice endosperm have been applied to a broad range of processes including differentially expressed proteins from the specific issues of plant tissues/organs [23], developmental stages [13,21,22,24-26], chalky and translucent parts [19], as well as under high temperature (HT) condition $[13,27,28]$ in which the starch biosynthesis-related proteins were affected and reported.

The posttranslational modifications (PTMs) refer to the chemical modification events resulting from the covalent attachment of chemical groups, such as phosphate, acetyl, succinyl, methyl, and oligosaccharides, to amino acid side chains of the particular proteins [29]. PTM is a crucial step for functional protein maturation and important in signal transduction, apoptosis, transcriptional regulation, etc., by changing the chemical nature 
of polypeptide chains during or after protein biosynthesis [29,30]. Recently, a number of PTMs have been identified and verified by many highly effective techniques, coupled with database and bioinformatics tools. In rice endosperm, PTMs targeted starch biosynthesis proteins have been identified including phosphorylation [27,28,31], acetylation [30,32-34], succinylation [34], malonylation [35], and lysine 2-hydroxyisobutyrylation [36].

As the global population grows, it is expected that, by 2035, additional demand of approximately 112 million metric tons of rice needs to be produced to keep food security [37]. Understanding the function of proteomics and PTMs in rice seeds will contribute to our understanding of the mechanism and regulation of starch biosynthesis, which is one of the most important topics for high-yield and high-quality rice production [8,28,38,39]. This review summarizes the current knowledge in starch biosynthesis proteins through the studies of proteomics and PTMs, delving into the contribution of starch biosynthesis proteins to starch properties and functionality.

\section{Significant Proteins for Starch Biosynthesis in Rice Seeds}

\subsection{Amylose and Amylopectin Biosynthesis}

The enzymatic machinery for starch biosynthesis is summarized in Figure 2. AGPase (EC 2.7.7.27), a step limiting for starch biosynthesis [40,41], is a heterotetramer composed of large and small subunits, which catalyzes the glucose-1-phosphate (G1P) to ADPglucose [9,14,42,43]. In rice, seven AGPase subunits were reported [44]. To promote an $\alpha-1,4$ bond and elongate the glucan chain, starch synthases (SSs) (EC 2.4.1.21) participate in the transfer of a glucosyl moiety from ADPglucose to the nonreducing end of the existing chains [45,46]. SSs are clustered into five classes including soluble SS I (SSI), SSII, SSIII, SSIV, and GBSS [45]. Two GBSS isoforms of rice-GBSSI and GBSSII-are primarily expressed in endosperm and leaves, respectively [44]. GBSSI is the only enzyme responsible for amylose biosynthesis (Figure 2).

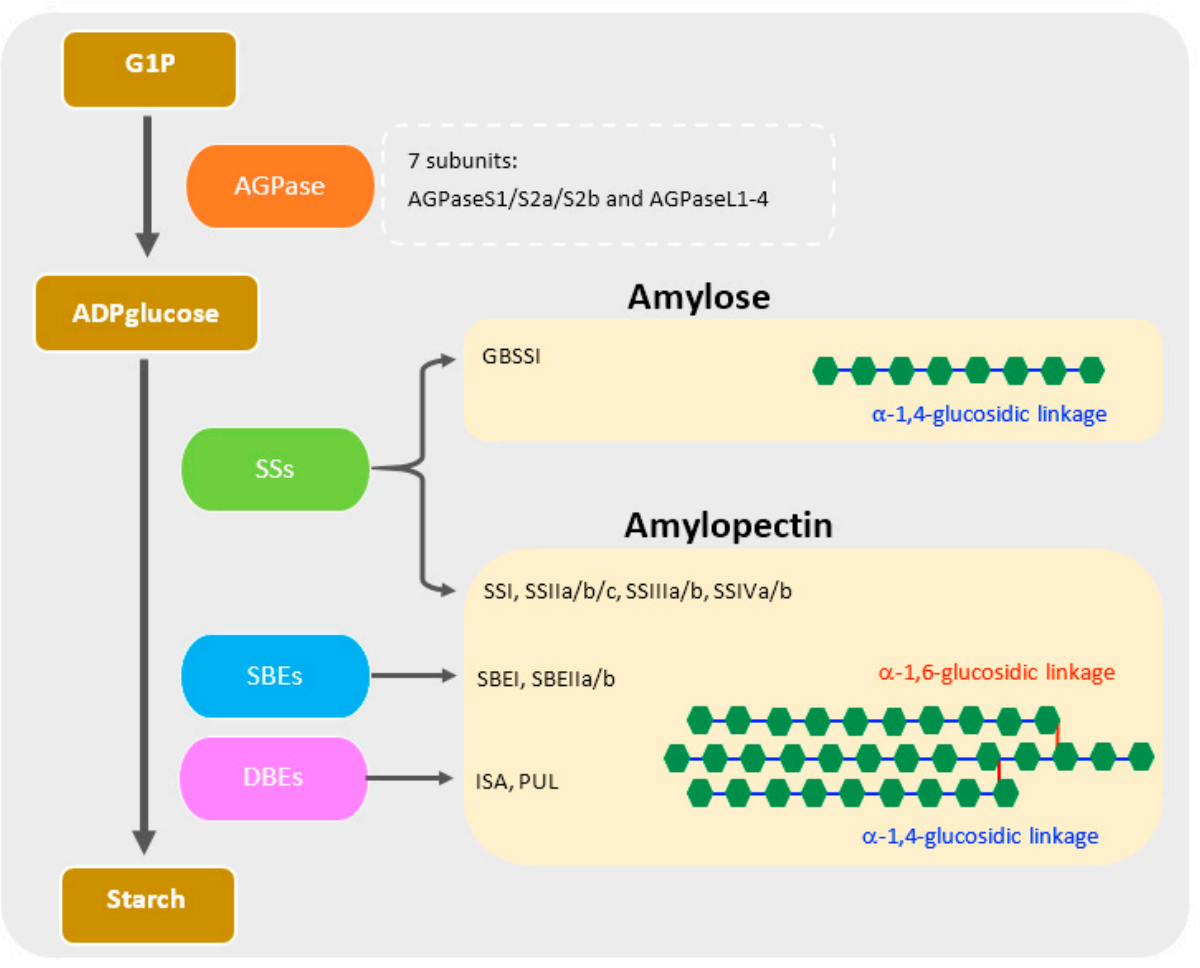

Figure 2. Brief schematic of the major proteins involved in starch biosynthesis in rice endosperm. Amylose and amylopectin are composed of glucose units (green rectangle) with $\alpha$-1,4-glucosidic linkage (blue line). The branch chains of amylopectin are connected through $\alpha-1,6$-glucosidic linkage (red line). 
In contrast, amylopectin, as compared with amylose, generally has a distinct fine structure and is synthesized by three main enzymes including SS, starch branching enzyme (BE), and starch debranching enzyme (DBE) [47]. The SSs play a crucial role in the elongation of $\alpha-1,4$-glucosidic chains and also regulating the quality and quantity of starch, especially in defining amylopectin chain-length distribution [11,47]. In rice, SSs contain multiple paralogs including SSI, SSIIa(SSII-3)/IIb(SSII-2)/IIc(SSII-1), SSIIIa(SSIII-2)/IIIb(SSIII-1), and SSIVa(SSIV-1)/IVb(SSIV-2) [45]. Among those isoforms, SSI, SSIIa, and SSIIIa are responsible for priming the short degree of polymerization (DP) 6 to 7 chains [15], short A and $B_{1}$ [42], and $B_{2}-B_{4}$ chains ( $D P \geq 30$ ) [43], respectively.

BEs (EC 2.4.1.18) specifically introduce the branch point, the $\alpha$-1,6-glucosidic linkage into the glucan chain by cutting the $\alpha$-1,4-linked glucan and also transferring to another chain at the 6-hydroxyl position and thus is considered as a key enzyme regulating amylopectin structure [48]. Three different isoforms of BEs including BEI, BEIIa, and BEIIb are present in rice endosperm [47]. BEI forms a variety of both short chains and intermediate chains (DP $\leq 40)$ by attacking the branched glucan in both the outer and inner chains of amylopectin [49]. Conversely, BEIIa and BEIIb function only in the outer amylopectin structure and specifically responsible for transferring the short chain of DP 6-15 and DP 6-7, respectively [47,49].

DBEs (EC 3.2.1.10) are composed of two types, isoamylase (ISA; EC 3.2.1.68) and pullulanase (PUL; EC 3.2.1.41), and hydrolyze the improper $\alpha-1,6$-glucans [47]. Both ISA and PUL debranch the amylopectin as well as other substrates, i.e., glycogen and phytoglycogen, for ISA and pullulan for PUL [47]. However, the improperly located branches are mainly removed by ISA and partially by PUL [50].

Besides those main enzymes, starch phosphorylase (Pho; EC 2.4.1.1) also plays a crucial role in starch biosynthesis and degradation [51-53]. Pho catalyzes the phosphorolytic of the outermost glucose residue to generate G1P, which is reversibly added to the end of $\alpha$ glucan chains [53], and recently, Pho is reported to play a crucial role in starch biosynthesis at low temperature [54]. Pho composted of a plastidial form or Pho1 (Pho-L) and a cytosolic form known as Pho2 (Pho-H) and both forms are different in terms of structure, kinetic properties, the expression pattern, and subcellular localization [53]. The enzyme activity of Pho1 is observed only in the endosperm of rice, while Pho2 is found in both endosperm and photosynthetic organs [53]. In addition, G1P is also the result of the reaction of plastidic phosphoglucomutase (PGM; EC 5.4.2.2), which catalyzes the conversion of G6P to G1P [55].

\subsection{Phosphorylation and Dephosphorylation of Glucan Chains}

Phosphorylation is only known in vivo covalent modification of starch. Two important isoforms of glucan water dikinase (GWD), GWD1 (EC 2.7.9.4) and phospho glucan water dikinase (PWD, EC 2.7.9.5) catalyze the phosphorylation at the $\mathrm{C} 6$ and $\mathrm{C} 3$ positions of glucosyl residues in amylopectin, respectively [56-59]. Both GWDs preferably phosphorylate the longer amylopectin chains at a range of DP 30-100 [57,60] and disrupt the glucan chains to access hydration [61]. The reduction of GWDs contributes to starch degradation by $\alpha$-amylase (EC 3.2.1.1) [62]. In rice, OsGWD1 (Os06g0498400) is responsible for leaf starch excess1 (LSE1) [63]. The LSE1 mutant lacked exons 22-32 displayed a higher starch content (5-10-fold) and lower phosphorylation $(0.05 \pm 0.02 \%)$ in the leaf blades, compared with those of wild type [63]. In addition, the LSE1 mutant had fewer panicles, lower ripened grains, smaller grains, and a lower grain yield, as compared to those of the wild type. Overexpression of potato GWD1 in rice enhanced the phosphorylation at both C6 (9-fold) and C3 (2-fold) positions, increased amylose content, and displayed a minor change in starch granule morphology of endosperm [64]. Besides the alteration of starch properties and functionality $[63,65,66]$, starch phosphorylation also interrupts the crystalline structure of amylopectin [67].

Dephosphorylation is an essential mechanism required for starch degradation [68]. Starch Excess4 (SEX4, EC 4.3.1.3.48) catalyzes the removal of phosphate groups at both C3 and C6 positions $[68,69]$, while Like Sex Four2 (LSF2) specifically dephosphorylates 
at C3 position [69]. In Arabidopsis leaves, the deficiency of SEX4 caused an increase in starch accumulation $[68,70]$, but a loss of LSF2 was found to have no obvious effects on starch levels [69]. Even though SEX4 and LSF2 play a crucial role in the dephosphorylation of Arabidopsis, their biological function remains unclear in rice endosperm. In addition, it was found that SEX4 was primarily expressed in the anthers of rice [71]. Recently, OsSEX4 (LOC_Os03g01750/Os03g0107800)-knockdown rice caused an increase in starch accumulation in suspension-cultured cells, leaves, and rice straw, indicating that the function of OSSEX4 is conserved with Arabidopsis [65]. The transgenic rice plants also exhibited a chalky grain phenotype and had no effects on vegetative growth and grain yield [65].

\subsection{Disproportionation to Nonreducing End of Starch}

The disproportionating enzyme (DPE, EC 2.4.1.25), a 4- $\alpha$-glucanotransferase, cleaves the $\alpha-1,4$ glucosidic bond, transfers the glucan moiety to the nonreducing end, and finally forms a new 1,4 glucosidic bond [66,72,73]. There are two isoforms of DPEs, plastidlocated DPE1 and cytoplasm-located DPE2, which differ in expression profiles, subcellular localization, protein structure, and reaction properties [72,74]. The identified OsDPE1 and OsDPE2 are composed of 594 and 946 amino acids, respectively [72]. Both DPEs showed the conserved domain of glucoside hydrolase of family 77 (GH77). The OsDPE1 contains only one domain of GH77, while the OsDPE2 has two copies of GH77 at the C-terminal and two copies of N-terminal carbohydrate-binding module 20 (CBM20) [72]. The activities of DPEs are different; OsDPE1 catalyzes the maltotriose transfer reaction by using the glucose as its acceptor, whereas OsDPE2 participates in the glucose transfer reaction from maltose to glycogen acceptor [72]. Recently, DPE1 mediates the reaction of transferring maltooligosyl units from amylose and amylopectin to amylopectin [73].

\subsection{Starch Granule Initiation}

The initiation of starch granules is recently studied in order to understand the mechanisms and factors that influence the number of granules per plastid and the morphogenesis of granules [75]. Several key proteins playing a crucial role in granule initiation were discovered through the homologs of Protein Targeting to Starch (PTST) proteins [75,76]. PTST contains an N-terminal coiled-coil domain and a C-terminal carbohydrate-binding module 48 (CBM48) mediating protein-protein interaction and starch-binding domain, respectively [77,78]. In Arabidopsis chloroplast, PTST1 interacts directly with GBSS via the coiled-coil domain in the stroma and then locates to starch granules by using the CBM48 domain $[78,79]$. PTST2 interacts with SS4 and soluble maltooligosaccharides (MOS), while PTST3 interacts with PTST2 [80]. In addition, PTST2 is also associated with Mar-Binding Filament Protein (MFP1) to facilitate the normal PTST2 localization [81]. Therefore, the executive functions of PTST1, 2, and 3 are required for amylose biosynthesis, normal granule initiation, and cofunction with PTST2, respectively [80].

In rice, the functions of GBSS-binding protein (OsGBP) and Floury Endosperm6 (FLO6) are similar to PTST1 and PTST2, respectively. A newly identified OsGBP interacts directly with both GBSSI and GBSSII in yeast two-hybrid assay [82]. The coiled-coil domain is responsible for GBSS binding, while the CBM48 is essential for targeting GBSSs to starch granules during amylose biosynthesis [82]. Based on the CRISPR/Cas9 gene editing, mRNA and protein abundance of osgbp mutants were significantly decreased in both leaves and grains, compared to wild type, leading to the reduction of starch content and number of starch granules with smaller size in leave and the presence of large chalkiness area in the endosperm [82].

FLO6 plays an essential role in starch granule formation and contains $\mathrm{N}$-terminal transit peptide and C-terminal CBM48 domain for plastid localization and binding to starch, respectively [83]. FLO6 interacts with ISA1 via its N-terminus with no effect on the enzyme activity. As compared to the wild type, the flo6 mutant showed many smaller granules with irregular shapes and rough surfaces [83]. 


\section{Proteomic Profiling of Starch Biosynthesis-Related Proteins}

The proteome of each living cell refers to the entire proteins expressed by a genome, which is highly dynamic and altering in response to intra- and extracellular factors across time points [18]. With different purposes of proteomics analysis, proteins involving starch biosynthesis of rice endosperm have been intensively studied (Tables 1-3).

\subsection{Specific Starch Biosynthesis-Related Proteins in Rice Seeds}

To identify the tissue-specific expression in rice and understand the mechanisms that regulate starch biosynthesis, a total of 1022, 1350, and 877 unique proteins were identified from leaf, root, and seed tissues of rice, respectively, by using both 2-DE and high-performance liquid chromatography-tandem mass spectrometry (HPLC-MS/MS) coupled with multidimensional protein identification technology (MudPIT) [23]. The unique peptides of starch biosynthesis-related proteins were achieved for $7.43 \%(162 / 2180)$ of those from the root, followed by $2.29 \%(54 / 2358)$ and $0.37 \%$ (10/2712) from leaf and root tissues, respectively. Pho, AMY, ISA, and PGM were also observed in root tissue. AGPase and GBSS were detected in the leaf, while only PGM was observed in all three tissues (leaf, root, and seed) [23] (Table 1). At the mature stage of rice endosperm, 14 starch biosynthesis proteins were identified as the starch granule-associated proteins, and additional Hsp70, putative Brittle-1 protein, and PPDK were also identified (Table 1) [32].

Table 1. List of starch biosynthesis proteins of rice endosperm based on proteomics in response to the organ-/tissuespecific differences.

\begin{tabular}{|c|c|c|c|c|}
\hline Sample & Aim of Study & Technique & Identified Proteins & Details of Results \\
\hline $\begin{array}{l}\text { leaf, root, and seed } \\
\text { of Nipponbare } \\
\text { (Japonica) [23] }\end{array}$ & $\begin{array}{l}\text { To identify protein } \\
\text { expression in leaf, } \\
\text { root (49 DAG), and } \\
\text { seed (14 DAG). }\end{array}$ & $\begin{array}{l}\text { 2-DE } \\
\text { HPLC-MS/MS } \\
\text { MudPIT }\end{array}$ & $\begin{array}{c}\text { AGPase (id: 7670) leaf, seed } \\
\text { AGPase small subunit } \\
\text { (id: 44074) leaf, seed } \\
\text { AGPase (id: 9904, 34550) seed } \\
\text { AGPase (id: 50182) leaf } \\
\text { GBSS (id: 31122) leaf, seed } \\
\text { GBSS (id: 31130) seed } \\
\text { SS precursor (id: 99443, 52528) seed } \\
\text { SS (id: 26269) seed } \\
\text { SBE isoform rbe3 (id: 36892) seed } \\
\text { SBE (id: 20648, 27094, 53238, } \\
\text { 55740) seed } \\
\text { DBE (id: 14376) } \\
\text { PhoH isoenzyme (id: 12500) seed } \\
\text { Pho1 (id: 32714) seed } \\
\text { AMY precursor (id: 21708) seed } \\
\text { AMY (id: 24707) seed } \\
\text { ISA (id: 23091) seed } \\
\text { ISA (id: 23496) seed } \\
\text { PGM, chloroplast precursor } \\
\text { (id: } 34039 \text { ) seed } \\
\text { PGM, cytoplasmic (id: } 38302 \text { ) leaf, } \\
\text { root, seed }\end{array}$ & $\begin{array}{c}\text { Proteins involving in starch } \\
\text { biosynthesis were observed in } \\
\text { both leaf and seed tissues. } \\
\text { Starch degradation-related } \\
\text { proteins were observed only in } \\
\text { seed tissue. } \\
\text { Two isoforms of small AGPase } \\
\text { subunit were detected in both } \\
\text { leaf and seed whereas another } \\
\text { two isoforms of large AGPase } \\
\text { subunit were identified only in } \\
\text { seed tissue. } \\
\text { The third isoform of large } \\
\text { AGPase subunit was observed } \\
\text { in leaf. }\end{array}$ \\
\hline \multirow{2}{*}{$\begin{array}{l}\text { DY1102 (Wuyujing3 } \\
\text { (Japonica) treated } \\
\text { with } 0.5 \% \text { ethyl } \\
\text { methanesulfonate } \\
\text { (EMS)) } \\
\text { (notched-belly } \\
\text { mutant with white } \\
\text { belly) [19] }\end{array}$} & \multirow{2}{*}{$\begin{array}{l}\text { To identify the } \\
\text { differentially } \\
\text { expressed proteins } \\
\text { between the chalky } \\
\text { and the translucent } \\
\text { parts of } \\
\text { DY1102 grains. }\end{array}$} & \multirow[b]{2}{*}{$\begin{array}{c}\text { iTRAQ } \\
\text { LC-MS/MS }\end{array}$} & \multirow{2}{*}{$\begin{array}{c}\text { AGPase, SSII, SSIII, SBE, Pho1, PGM, } \\
\text { AMY, and putative starch synthase } \\
\text { DULL1 (SSIIIa) }\end{array}$} & $\begin{array}{l}\text { Downregulation of AMY was } \\
\text { observed in chalky part. } \\
\text { Downregulation of AMY } \\
\text { contributes to starch hydrolysis } \\
\text { and the formation of chalkiness. }\end{array}$ \\
\hline & & & & $\begin{array}{l}\text { SSIIIa was one of the } \\
\text { differentially expressed proteins } \\
\text { and increased in chalky part. } \\
\text { The increase in SSIIIa expression } \\
\text { did not result in the increased } \\
\text { proportion of long amylopectin } \\
\text { chains (DP }>30 \text { ). }\end{array}$ \\
\hline
\end{tabular}


Table 1. Cont.

\begin{tabular}{|c|c|c|c|c|}
\hline Sample & Aim of Study & Technique & Identified Proteins & Details of Results \\
\hline $\begin{array}{l}\text { Nipponbare } \\
\text { (Japonica) [32] }\end{array}$ & $\begin{array}{c}\text { To develop a } \\
\text { method for rice } \\
\text { starch granule } \\
\text { purification from } \\
\text { mature endosperm } \\
\text { and identify starch } \\
\text { granule-associated } \\
\text { proteins. }\end{array}$ & LC-MS/MS & $\begin{array}{c}\text { AGPase S2, AGPase L1, } \\
\text { AGPase L2 } \\
\text { GBSSI, GBSSII } \\
\text { SBE 1, SBE3 } \\
\text { SSI, SSII-1, SSII-3, SSIIIa } \\
\text { PUL } \\
\text { Pho1 } \\
\text { ISA2 }\end{array}$ & $\begin{array}{l}\text { Besides } 14 \text { identified starch } \\
\text { biosynthesis proteins, the } \\
\text { other candidate starch } \\
\text { granule-associated proteins } \\
\text { involving in starch } \\
\text { biosynthesis were also } \\
\text { identified by LC-MS/MS } \\
\text { including Hsp70, putative } \\
\text { Brittle-1 protein, and PPDK. } \\
\text { Compared with Tris-HCl } \\
\text { buffer extraction method, } \\
\text { the proteome extracted by } \\
\text { the phenol buffer had more } \\
\text { proteins and displayed } \\
\text { almost all identified } \\
\text { proteins extracted by } \\
\text { Tris-HCl buffer. }\end{array}$ \\
\hline
\end{tabular}

Lin et al. [19] identified 113 differentially expressed proteins between the translucent and chalky parts of rice Wuyujing3. Among these, proteins in carbohydrate metabolism were the third most abundant $(15.0 \%)$ after the categories of protein synthesis, folding and degradation (27.4\%), and unidentified function (24.8\%). AGPase, SSII, SSIII, SSIIIa, SBE, Pho1, PGM, and AMY were identified by using the isobaric tags for relative and absolute quantification (iTRAQ) based on the upper and the bottom half of translucent and chalky grains (Table 1). The AMY was downregulated in the chalky part, which was responsible for the processes of starch hydrolysis and chalk formation [19]. SSIIIa functions in $\mathrm{B}_{2-4}$ chains elongation with the degree of polymerization (DP) $\geq 30$ [43]. In contrast, Lin et al. [19] found SSIIIa was increased in the chalky part, which was found the greater amount of short chain $(\mathrm{DP} \leq 12)$ and fewer medium and long chains, compared with the translucent parts.

\subsection{Starch Biosynthesis-Related Proteins in Different Developmental Stages of Rice Seeds}

In cereal endosperm cells, starch granules are synthesized and increase in number and volume until maturity based upon the synergy of multiple enzymes $[9,30,84,85]$. No starch accumulation was observed in rice endosperm at 2 days after flowering (DAF), and a small amount of starch was found in the pericarp at $4 \mathrm{DAF}$ [22]. A great accumulation of starch in endosperm was noticed after 8 DAF $[22,86]$. Endosperm remains equally milk white with no translucent region at 10 DAF [26] and 12 DAF [24]. Since the translucent region indicates the accumulation and packing of starch granule, half of the translucent area in the central endosperm were observed at 15 DAF $[24,26]$, while full translucent in the whole endosperm was noticed at 20 DAF [26]. However, rice seed development varies depending on genotypic and environmental conditions [25].

The identified starch biosynthesis-related proteins involved in rice endosperm development were summarized in Table 2. Over 400 protein spots were identified in Taichung Native 1 (TN 1) at 12 DAF [13]. GBSS (Waxy) was identified and increased the expression after 6 DAF [13]. 
Table 2. List of starch biosynthesis proteins of rice endosperm based on proteomics in response to different developmental stages.

\begin{tabular}{|c|c|c|c|c|}
\hline Sample & Aim of Study & Technique & $\begin{array}{l}\text { Identified } \\
\text { Proteins }\end{array}$ & Details of Results \\
\hline $\begin{array}{l}\text { Taichung Native } 1 \\
\text { (TN 1, Indica) and } \\
\text { Tainung 67, (TNG } \\
67, \text { Japonica) [13] }\end{array}$ & $\begin{array}{l}\text { To investigate the changes in protein } \\
\text { expression patterns during rice } \\
\text { caryopsis development }(6,9,12,15, \\
\text { and } 32 \mathrm{DAF}) .\end{array}$ & $\begin{array}{c}\text { 2-DE } \\
\text { LC-MS/MS }\end{array}$ & GBSS (Waxy) & $\begin{array}{l}\text { The expression of GBSS increased } \\
\text { after } 6 \text { DAF was coincident with } \\
\text { the increase in amylose content. } \\
\text { GBSS protein was highly } \\
\text { expressed in kernels of rice with } \\
\text { high amylose content (TN1). }\end{array}$ \\
\hline \multirow[t]{3}{*}{$\begin{array}{c}\text { Nipponbare } \\
\text { (Japonica) [22] }\end{array}$} & \multirow{3}{*}{$\begin{array}{l}\text { To study the protein expression } \\
\text { profiles related to grain filling during } \\
\text { 6-20 DAF. }\end{array}$} & \multirow[t]{3}{*}{$\begin{array}{c}\text { 2-DE } \\
\text { MALDI-TOF/TOF }\end{array}$} & $\begin{array}{l}\text { ISA I, AMY, } \\
\text { Pho, PGM, } \\
\text { AGPaseL2, } \\
\text { AGPaseL3, } \\
\text { AGPaseS2a/b }\end{array}$ & $\begin{array}{l}\text { All identified proteins were } \\
\text { continuously increased from } 6 \text { to } \\
20 \text { DAF. } \\
\text { Some AGPase isoforms had the } \\
\text { highest peak of protein expression } \\
\text { at } 16 \text { DAF and decrease thereafter. }\end{array}$ \\
\hline & & & ISA3 & $\begin{array}{l}\text { ISA3 increased at } 6 \text { DAF, showed } \\
\text { the highest expression at } 10 \mathrm{DAF}, \\
\text { and decreased thereafter. }\end{array}$ \\
\hline & & & SSI & No result of expression pattern. \\
\hline $\begin{array}{l}\text { Zhonghua } 10 \\
\text { (Japonica) [24] }\end{array}$ & $\begin{array}{l}\text { To study the cellular features and } \\
\text { proteomics of rice endosperm from } 12 \text {, } \\
15 \text {, and } 18 \text { DAF. }\end{array}$ & $\begin{array}{l}\text { 2D-DIGE } \\
\text { MALDI-TOF/ } \\
\text { TOF-MS }\end{array}$ & $\begin{array}{c}\text { PUL } \\
\text { Pho1 } \\
\text { AGPase L } \\
\text { AGPase S2 }\end{array}$ & $\begin{array}{l}\text { Most of the protein expression } \\
\text { patterns showed increase in } \\
\text { abundance from } 12 \text { to } 18 \text { DAF. } \\
\text { Some isoforms of PUL and } \\
\text { AGPase S2 had the highest peak of } \\
\text { expression at } 15 \text { DAF. } \\
\text { Pho1 decreased the expression } \\
\text { level form 12-18 DAF. } \\
\text { AGPase L showed the highest } \\
\text { variation of expression patterns } \\
\text { including the expression levels } \\
\text { continuously decreased and } \\
\text { increased from 12-18 DAF, showed } \\
\text { the highest peak and lowest peak } \\
\text { at } 15 \text { DAF. } \\
\text { The completion of starch granule } \\
\text { packing was firstly observed in the } \\
\text { inner part of endosperm at } 15 \text { DAF } \\
\text { and showed entire endosperm at } \\
18 \text { DAF. } \\
\text { AGPase L and Pho1 were } \\
\text { significantly coexpressed with } \\
\text { proteins in redox regulation (SOD } \\
\text { and APX, respectively) }\end{array}$ \\
\hline $\begin{array}{l}\text { Ilpumbyeo } \\
\text { (Japonica) [25] }\end{array}$ & $\begin{array}{l}\text { To identify the differentially expressed } \\
\text { proteins of rice grains at } 10,20,30 \mathrm{DAF} \\
\text { and the fully mature grain ( } 45 \mathrm{DAF}) \text {. }\end{array}$ & MudPIT & $\begin{array}{l}\text { Pho1 } \\
\text { PUL } \\
\text { AMY } \\
\text { SS 2-3 } \\
\text { GWD } \\
\text { SBE }\end{array}$ & $\begin{array}{l}\text { All identified } 6 \text { starch biosynthesis } \\
\text { proteins were reproducibly } \\
\text { identified and differentially } \\
\text { expressed during four stages (10, } \\
\text { 20,30, and } 45 \text { DAF). } \\
\text { All of these proteins had the } \\
\text { highest expression levels at the } \\
\text { fully mature grain except SS } 2-3 \text { in } \\
\text { which its abundance increased } \\
\text { until } 20 \text { DAF after that decreased } \\
\text { at } 30 \text { DAF and increased at fully } \\
\text { mature grain. } \\
\text { The authors suggested that the } \\
\text { expression profile of starch } \\
\text { biosynthesis proteins was similar } \\
\text { to previous research of } \\
\text { Xu et al. [22] }\end{array}$ \\
\hline
\end{tabular}


Table 2. Cont.

\begin{tabular}{|c|c|c|c|c|}
\hline Sample & Aim of Study & Technique & $\begin{array}{c}\text { Identified } \\
\text { Proteins }\end{array}$ & Details of Results \\
\hline \multirow{2}{*}{$\begin{array}{l}\text { Jinhui No. } 809 \\
\text { (Indica) [87] }\end{array}$} & \multirow{2}{*}{$\begin{array}{c}\text { To identify the differentially expressed } \\
\text { proteins between superior (SS) and } \\
\text { inferior spikelet (IS) at the early (EGS), } \\
\text { mid (MGS), and late (LGS) } \\
\text { grain-filling stages. }\end{array}$} & \multirow{2}{*}{$\begin{array}{c}\text { 2-DE } \\
\text { MALDI-TOF/MS } \\
\text { LC-ESI-MS/MS }\end{array}$} & $\begin{array}{l}\text { AGPase } \\
\text { GBSS } \\
\text { PUL }\end{array}$ & $\begin{array}{c}\text { AGPase, GBSS, and PUL isoforms } \\
\text { were downregulated in inferior } \\
\text { spikelets at EGS. }\end{array}$ \\
\hline & & & AGPase S & $\begin{array}{l}\text { AGPase S showed downregulation } \\
\text { in both MGS and LGS. }\end{array}$ \\
\hline $\begin{array}{l}\text { Jinhui No. } 809 \\
\text { (Indica) [88] }\end{array}$ & $\begin{array}{l}\text { To identify the differentially expressed } \\
\text { proteins of } 10 \mathrm{DAF} \text { superior spikelet (SS) } \\
\text { and } 10 \text { and } 20 \mathrm{DAF} \text { inferior spikelet (IS). }\end{array}$ & $\begin{array}{l}\text { 2-DE } \\
\text { MALDI-TOF/MS } \\
\text { LC-ESI-MS/MS }\end{array}$ & $\begin{array}{l}\text { AGPase } \\
\text { GBSS } \\
\text { SBE } 1 \\
\text { SBE } 3 \\
\text { PUL }\end{array}$ & $\begin{array}{l}\text { AGPase had lower expression } \\
\text { level in } 10 \text { DAF IS compared with } \\
\text { both } 10 \text { DAF SS and } 20 \text { DAF IS. } \\
\text { SBE 3, AGPase, PUL, and SBE } 1 \\
\text { were detected as the 14-3-3 } \\
\text { interacting proteins. } \\
\text { AGPase and GBSS might be } \\
\text { involved in the developmental } \\
\text { stagnancy stage (DSS) of IS } \\
\text { especially at the early } \\
\text { grain-filling stage. }\end{array}$ \\
\hline $\begin{array}{l}\text { Zhonghua } 10 \\
\text { (Japonica) [26] }\end{array}$ & $\begin{array}{c}\text { To identify the SGAPs of rice at } 10,15 \\
\text { and } 20 \text { DAF. }\end{array}$ & $\begin{array}{l}\text { 2D-DIGE } \\
\text { MALDI-TOF/ } \\
\text { TOF-MS }\end{array}$ & $\begin{array}{l}\text { Pho1 } \\
\text { PUL } \\
\text { SSI } \\
\text { AGPase L2 } \\
\text { GBSSI } \\
\text { AGPase S2a }\end{array}$ & $\begin{array}{l}\text { Protein abundance of Pho1, PUL, } \\
\text { SSI, and AGPase S2a slowly } \\
\text { increased from } 10 \text { to } 15 \text { DAF and } \\
\text { then drastically increased from } 15 \\
\text { to } 20 \text { DAF. } \\
\text { GBSSI showed linearly decreased } \\
\text { abundance levels from } 10 \text { to } \\
20 \text { DAF. } \\
\text { GBSSI and SSI were found only in } \\
\text { starch granule-associated } \\
\text { (SGA) form. } \\
\text { AGPase, Pho1, and PUL were } \\
\text { observed in both soluble and } \\
\text { SGA forms. }\end{array}$ \\
\hline
\end{tabular}

The 396 differentially expressed protein spots were identified in Nipponbare during the early (6-8 DAF), mid (8-12), and late (12-20) stages of rice seed development [22]. ISA I, AMY, DBE, Pho 1, PGM, and AGPase were increased from 6 to 20 DAF, while the expression level of ISA3 protein started to increase at $6 \mathrm{DAF}$, reached the highest level at 10 DAF, and decreased thereafter. During the late stage, the expression levels of PUL, Pho 1, and AGPase increased in abundance from 12 to 18 DAF [22].

Lee et al. [25] reported 4172 nonredundant proteins of fully mature seeds and 889, 913, 1095, and 899 proteins were identified during 10, 20, 30, and 45 DAF. Pho 1, PUL, AMY, SS 2-3, GWD, and SBE were differentially expressed among each interval stage and the highest protein abundance was observed at the fully mature grains (45 DAF). Among those proteins, PUL, AMY, and SBE increased until 20 DAF and slightly decreased at 30 DAF then rapidly increased at fully mature grain, suggesting that process of starch accumulation was intensive at 20 DAF [25].

Besides starch biosynthesis-related proteins, proteins involving in other metabolic processes such as glycolysis, TCA-cycle, lipid metabolism, and proteolysis were also detected at higher levels in the fully mature grain (desiccation phase), compared to the developing stages, suggesting that the accumulation of these proteins might be for seed germination [25].

Zhang et al. [87] found that AGPase, GBSS, and PUL were differentially expressed between superior and inferior spikelets during the rice grain-filling stage, which was downregulated in the inferior spikelets at the early stage. Western blotting indicated that AGPase was downregulated in the inferior spikelets at all stages of the early, mid, and late grain-filling stage, compared to superior spikelets [87]. In addition, SBE 3, AGPase, PUL, and SBE 1 were detected as the interacting proteins with 14-3-3 [88], which might play a crucial role in the termination of inferior spikelets' development. 
Yu et al. [26] identified 115 developmentally changed starch granule-associated proteins (SGAPs), with 39\% of which involving in starch biosynthesis. Pho1, PUL, SSI, and AGPase S2a slowly increased in abundance from 10 to 15 DAF and then rapidly increased from 15 to $20 \mathrm{DAF}$, while the levels of GBSSI abundance showed the linearly decreased from 10 to 20 DAF [26].

Overall, the expression patterns of proteins involving in starch biosynthesis, starch degradation, and starch phosphorylation are particularly responsible for rice seed development. Most of those reported proteins are continuously increased during 6-20 DAF. However, proteins involving in starch debranching, degradation (AMY, Pho1, and PUL), and phosphorylation (GWD) are markedly decreased at $30 \mathrm{DAF}$ and then increased to complete seed development.

\subsection{Starch Biosynthesis-Related Proteins Respond to High Temperature (HT)}

HT particularly affects the yield and quality of rice [89] but no significant changes were observed for seed morphology and size [90]. The effects of HT on starch biosynthesisrelated proteins were summarized in Table 3.

Table 3. List of starch biosynthesis-related proteins of rice endosperm based on proteomics in response to HT.

\begin{tabular}{|c|c|c|c|c|}
\hline Sample & Aim of Study & Technique & $\begin{array}{l}\text { Identified } \\
\text { Proteins }\end{array}$ & Details of Results \\
\hline $\begin{array}{l}\text { Taichung Native } 1 \\
\text { (TN 1, Indica) and } \\
\text { Tainung 67, (TNG } \\
67, \text { Japonica) [13] }\end{array}$ & $\begin{array}{l}\text { To determine the } \\
\text { candidate proteins } \\
\text { associated with grain } \\
\text { quality under HT, } \\
35 / 30{ }^{\circ} \mathrm{C} \text { (day/night). }\end{array}$ & $\begin{array}{c}\text { 2-DE } \\
\text { LC-MS/MS }\end{array}$ & GBSS (Waxy) & $\begin{array}{l}\text { HT caused the reduction of GBSS in } \\
\text { TGN67 and decreased the levels of } \\
\text { amylose content of TNG67 at } 15 \text { DAF } \\
(12.3 \pm 0.5 \%) \text { compared with those } \\
(15.6 \pm 0.4 \%) \text { under the control } \\
\text { temperature }\left(30 / 25^{\circ} \mathrm{C}\right) \text {. } \\
\text { Protein expression of TN1 showed } \\
\text { relatively stable in both HT and } \\
\text { control conditions. } \\
\text { TNG67 showed more sensitivity to HT } \\
\text { than TN1. }\end{array}$ \\
\hline 9311 (Indica) [91] & $\begin{array}{c}\text { To identify the } \\
\text { differentially } \\
\text { accumulated proteins } \\
\text { of rice at } 5,10,15 \text {, and } \\
20 \text { DAF under day HT } \\
\left(\mathrm{DHT}, 35 / 27^{\circ} \mathrm{C}\right) \text { and } \\
\text { night } \mathrm{HT}(\mathrm{NHT} \text {, } \\
\left.27 / 35^{\circ} \mathrm{C}\right) .\end{array}$ & $\begin{array}{c}\text { 2-DE } \\
\text { MALDI-TOF } \\
\text { MS/MS }\end{array}$ & $\begin{array}{l}\text { PGM } \\
\text { PUL }\end{array}$ & $\begin{array}{l}\text { One and five isoforms of PUL and PGM } \\
\text { were differentially accumulated in } \\
\text { response to DHT and NHT and detected } \\
\text { in all 5, 10, 15, and } 20 \text { DAF with different } \\
\text { accumulation patterns. } \\
\text { Three PUL isoforms (spot } 34,35 \text {, and 36) } \\
\text { were increased in parallel abundance } \\
\text { from } 5 \text { to } 20 \text { DAF, while another (spot } 37 \\
\text { and 38) showed slowly increase at 5-10 } \\
\text { DAF and highly increase in abundance at } \\
15 \text { and } 20 \text { DAF. }\end{array}$ \\
\hline $\begin{array}{c}\text { XN0437T } \\
\text { (heat-tolerant) } \\
\text { XN0437S } \\
\text { (heat-sensitive) [89] }\end{array}$ & $\begin{array}{l}\text { To identify the } \\
\text { differentially expressed } \\
\text { proteins during rice } \\
\text { grain development at } 1 \text {, } \\
3 \text {, and } 5 \text { day after HT } \\
\text { treatment } \\
\left(38.0 \pm 0.5^{\circ} \mathrm{C}\right) \\
\text { compared with control } \\
\left(25.0 \pm 0.5^{\circ} \mathrm{C}\right)\end{array}$ & $\begin{array}{c}\text { 2-DE } \\
\text { MALDI- } \\
\text { TOF/TOF } \\
\text { MS }\end{array}$ & $\begin{array}{c}\text { PUL } \\
\text { DBE } \\
\text { GBSS } \\
\text { AGPase L }\end{array}$ & $\begin{array}{c}\text { All } 4 \text { proteins involving in starch } \\
\text { biosynthesis showed downregulation in } \\
\text { both rice lines under HT stress compared } \\
\text { with the control treatment. } \\
\text { AGPase L was higher accumulated in the } \\
\text { heat-tolerant rice at } 1 \text { day after HT and } \\
\text { showed lower accumulation at } 3 \text { and } \\
5 \text { days after HT compared to } \\
\text { heat-sensitive rice. } \\
\text { PUL, DBE, and GBSS had lower } \\
\text { expression levels in heat-tolerant rice at } \\
\text { all three-time points. }\end{array}$ \\
\hline
\end{tabular}


Table 3. Cont.

\begin{tabular}{|c|c|c|c|c|}
\hline Sample & Aim of Study & Technique & $\begin{array}{l}\text { Identified } \\
\text { Proteins }\end{array}$ & Details of Results \\
\hline \multirow{3}{*}{$\begin{array}{l}\text { Perfect and chalky } \\
\text { rice grains } \\
\text { (Koshihikari } \\
\text { (Japonica)) [92] }\end{array}$} & \multirow{3}{*}{$\begin{array}{l}\text { To study the proteomic } \\
\text { profile of the } \\
\text { translucent and opaque } \\
\text { grains under moderate } \\
\text { (in } 2009,24.4^{\circ} \mathrm{C} \text { ) and } \\
\mathrm{HT} \text { (in } 2010 \text {, } \\
28.0^{\circ} \mathrm{C} \text { ) conditions. }\end{array}$} & \multirow{3}{*}{$\begin{array}{l}\text { iTRAQ } \\
\text { MS/MS }\end{array}$} & $\begin{array}{l}\text { SSI } \\
\text { SSII } \\
\text { PUL } \\
\text { GBSSI } \\
\text { BEIIb }\end{array}$ & $\begin{array}{l}\text { All identified proteins showed } \\
\text { downregulation in chalky rice compared to } \\
\text { perfect grain. } \\
\text { Protein expression of SSII, PUL, and BEIIb } \\
\text { under moderate temperature was lower } \\
\text { than HT condition, while the others, SSI and } \\
\text { GBSSI showed higher abundance under HT. }\end{array}$ \\
\hline & & & $\begin{array}{c}\text { AMY } \\
\text { (AmyII-3) }\end{array}$ & $\begin{array}{c}\text { AMY showed upregulation in chalky rice in } \\
\text { both conditions and chalky rice under HT } \\
\text { stress had higher AMY abundance than } \\
\text { moderate temperature. }\end{array}$ \\
\hline & & & $\begin{array}{l}\text { DBE } \\
\text { BEI }\end{array}$ & $\begin{array}{l}\text { Both DBE and BEI were increased in HT but } \\
\text { downregulated in moderate temperature. }\end{array}$ \\
\hline \multirow{6}{*}{$\begin{array}{l}\text { KDML105 } \\
\text { (Indica) [90] }\end{array}$} & \multirow{6}{*}{$\begin{array}{l}\text { To identify the } \\
\text { differentially changed } \\
\text { proteins of rice grains } \\
\text { under heat stress } \\
\left(40 / 26^{\circ} \mathrm{C}\right) \text { at the milky, } \\
\text { dough, and } \\
\text { mature stages. }\end{array}$} & \multirow{6}{*}{$\begin{array}{l}\text { nanoLC- } \\
\text { MS/MS }\end{array}$} & AMY & $\begin{array}{l}\text { AMY showed the highest in abundance at } \\
\text { milky then decreased in dough and } \\
\text { disappeared at mature stage. }\end{array}$ \\
\hline & & & AGPase & $\begin{array}{l}\text { AGPase had the un-change expression in } \\
\text { both milky and dough stages and double } \\
\text { increased in mature stage. }\end{array}$ \\
\hline & & & $\begin{array}{l}\text { SBEI } \\
\text { GBSSI }\end{array}$ & $\begin{array}{c}\text { Protein abundance of both SBEI and GBSSI } \\
\text { was increased almost three times from } \\
\text { milky to dough stages. } \\
\text { Both SBEI and GBSSI were not found at } \\
\text { mature stage. }\end{array}$ \\
\hline & & & AGPase L2 & $\begin{array}{c}\text { AGPase L2 was detected only at } \\
\text { dough stage. }\end{array}$ \\
\hline & & & $\begin{array}{l}\text { SBE3 } \\
\text { AGPase L2 } \\
\text { SSIIa } \\
\text { SSI }\end{array}$ & $\begin{array}{l}\text { All proteins were detected only in milky } \\
\text { stage in which the AGPase L2 showed the } \\
\text { highest abundance followed by SSI, SBE3, } \\
\text { and SS IIa. }\end{array}$ \\
\hline & & & ISA & $\begin{array}{c}\text { ISA was detected in both milky and mature } \\
\text { stages and showed the highest abundance } \\
\text { at mature stage. }\end{array}$ \\
\hline
\end{tabular}

HT at $35 / 30{ }^{\circ} \mathrm{C}$ (day/night) decreased the GBSS abundance of japonica rice (TNG $67)$, leading to the lower amylose content observed at $15 \mathrm{DAF}(12.3 \pm 0.5 \%)$, compared with the control temperature at $30 / 25^{\circ} \mathrm{C}(15.6 \pm 0.4 \%)$, while those of indica rice (TN1) were relatively stable under both temperatures [13]. According to the HT condition during grain filling, chalkiness occurrence is increased, and loosely packed of abnormal starch granules were observed in rice endosperm [92,93]. Li et al. [91] reported that the conditions of both day high temperature $\left(35 / 27^{\circ} \mathrm{C}, \mathrm{DHT}\right)$ and night high temperature $\left(27 / 35^{\circ} \mathrm{C}\right.$, NHT) caused a higher percentage of chalkiness but lower levels of brown rice rate, milled rice rate, head rice rate, amylose content, and gel consistency, compared to the control condition $\left(28 / 20^{\circ} \mathrm{C}\right)$. Besides a PGM isoform, five isoforms of PUL were detected and differentially accumulated in response to DHT and NHT [91]. Compared to heat-sensitive rice (XN0437S), the lower abundance of PUL, DBE, and GBSS was observed in heat-tolerant rice $(\mathrm{XN} 0437 \mathrm{~T})$ at 1 day $(\mathrm{d}), 3 \mathrm{~d}$, and $5 \mathrm{~d}$ of HT stress $\left(38.0 \pm 0.5^{\circ} \mathrm{C}\right)$ [89]. The higher accumulation of AGPase $\mathrm{L}$ was found in heat-tolerant rice at $1 \mathrm{~d}$ and decreased at $3 \mathrm{~d}$ and $5 \mathrm{~d}$ of HT stress [89]. 
Compared to the perfect grain, SSI, SSII, PUL, GBSSI, and BEIIb were downregulated, while AMY (AmyII-3) was increased in chalky grain in both moderate $\left(24.4^{\circ} \mathrm{C}\right)$ and HT $\left(28.0^{\circ} \mathrm{C}\right)$ conditions [92]. DBE and BEI were down- and increased in moderate and HT conditions, respectively [92].

Moreover, Timabud et al. [90] reported that heat stress affected the abundance of starch biosynthesis proteins in milky, dough, and mature stages. Under heat treatment, SBE3, AGPase L2, SSIIa, and SSI were expressed and detected only at the milky stage, while SBEI and GBSSI were increased in abundance from milky to the dough but not detectable at the mature stage. AMY was highly expressed at the milky, compared to the dough stage, whereas AGPase was increased in the highest abundance at the mature stage. AGPase S2 was differentially expressed in both dough and mature stages, while ISA was detected at the milky and mature stages [90]. In addition, grains weight under HT were increased more rapidly than the control, especially from late milky to middle dough stages $[90,91]$.

Altogether, HT activates starch degradation rather than starch biosynthesis through the reduction of GBSSI, SSI, SSII, SBEIIb, DBE, and PUL, while some proteins, such as AGPase L, GBSSI, SBEI, and AMY are increased and contributed to the lower amylose content and the higher the chalkiness rate in rice endosperm.

\section{Starch Biosynthesis-Related Proteins Targeted by PTMs}

PTMs can alter structure formation, activity, stability, structure, and localization of proteins, which are necessary for cellular functions [84,85]. Five types of PTMs targeting starch biosynthesis proteins have been reported from rice seeds (Figures 3-5).

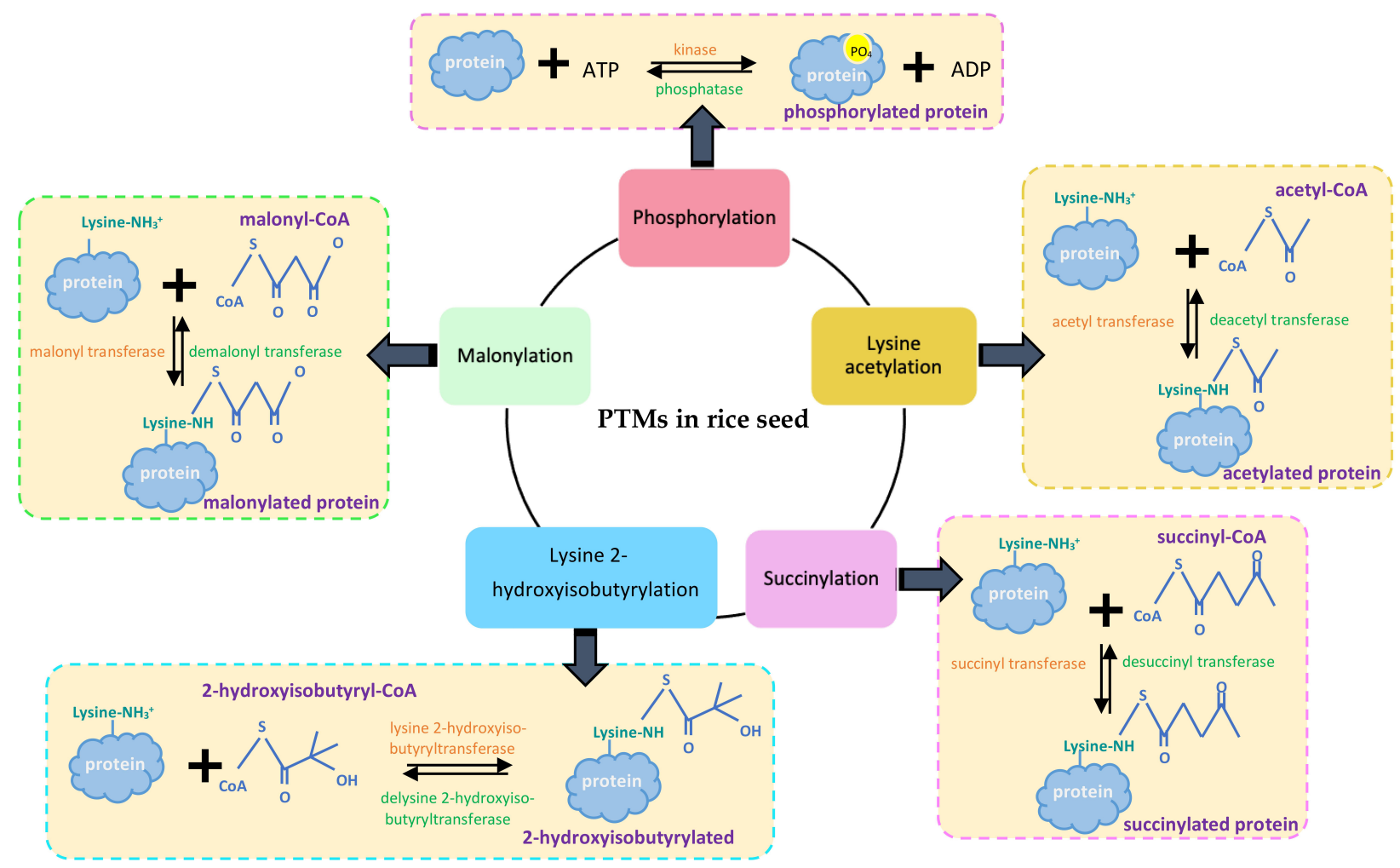

Figure 3. Five types of PTMs targeting starch biosynthesis proteins identified from rice seeds. 


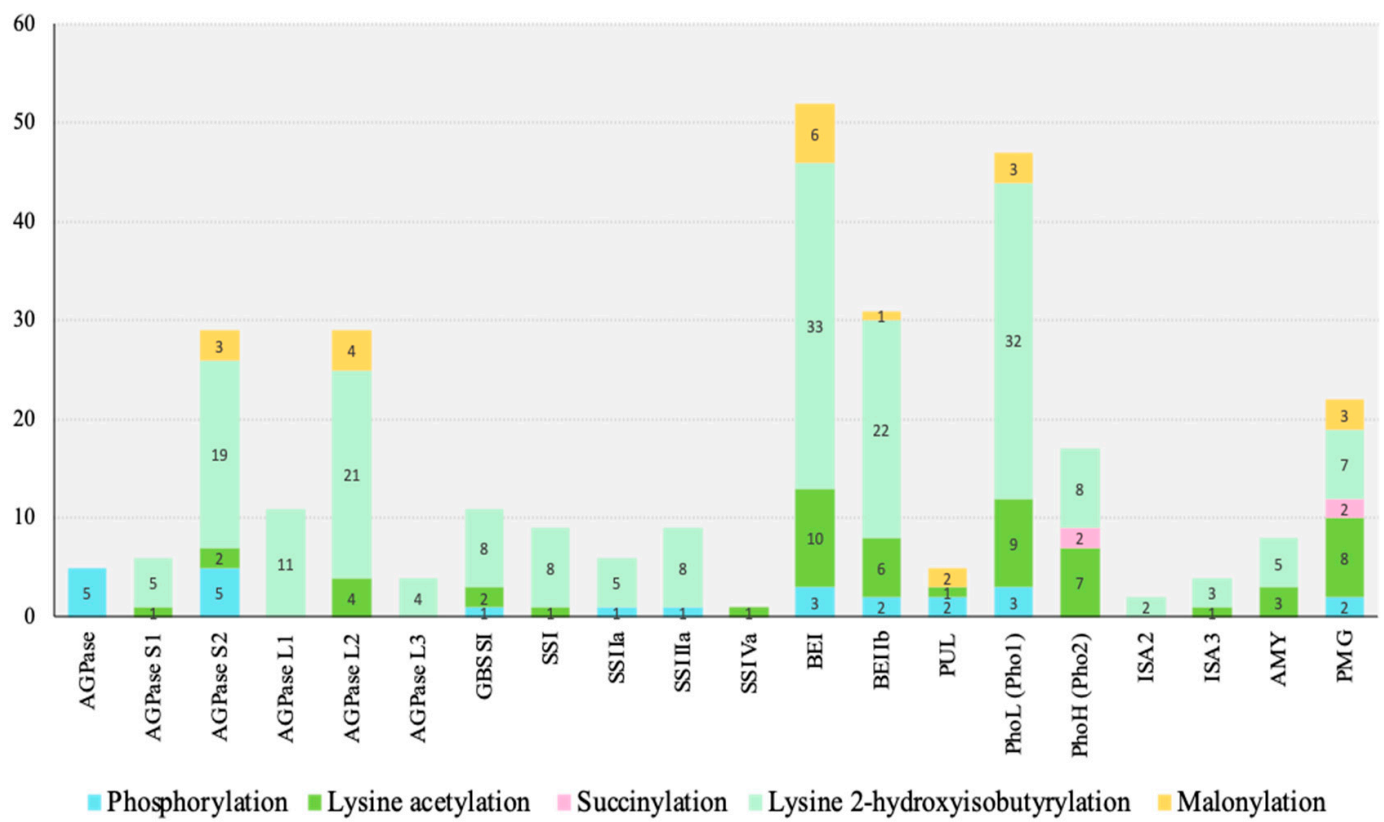

Figure 4. Summary of PTMs targeting starch biosynthesis-related proteins in rice seeds. The number on stacked bar indicates total target sites of PTM(s) identified for each protein.

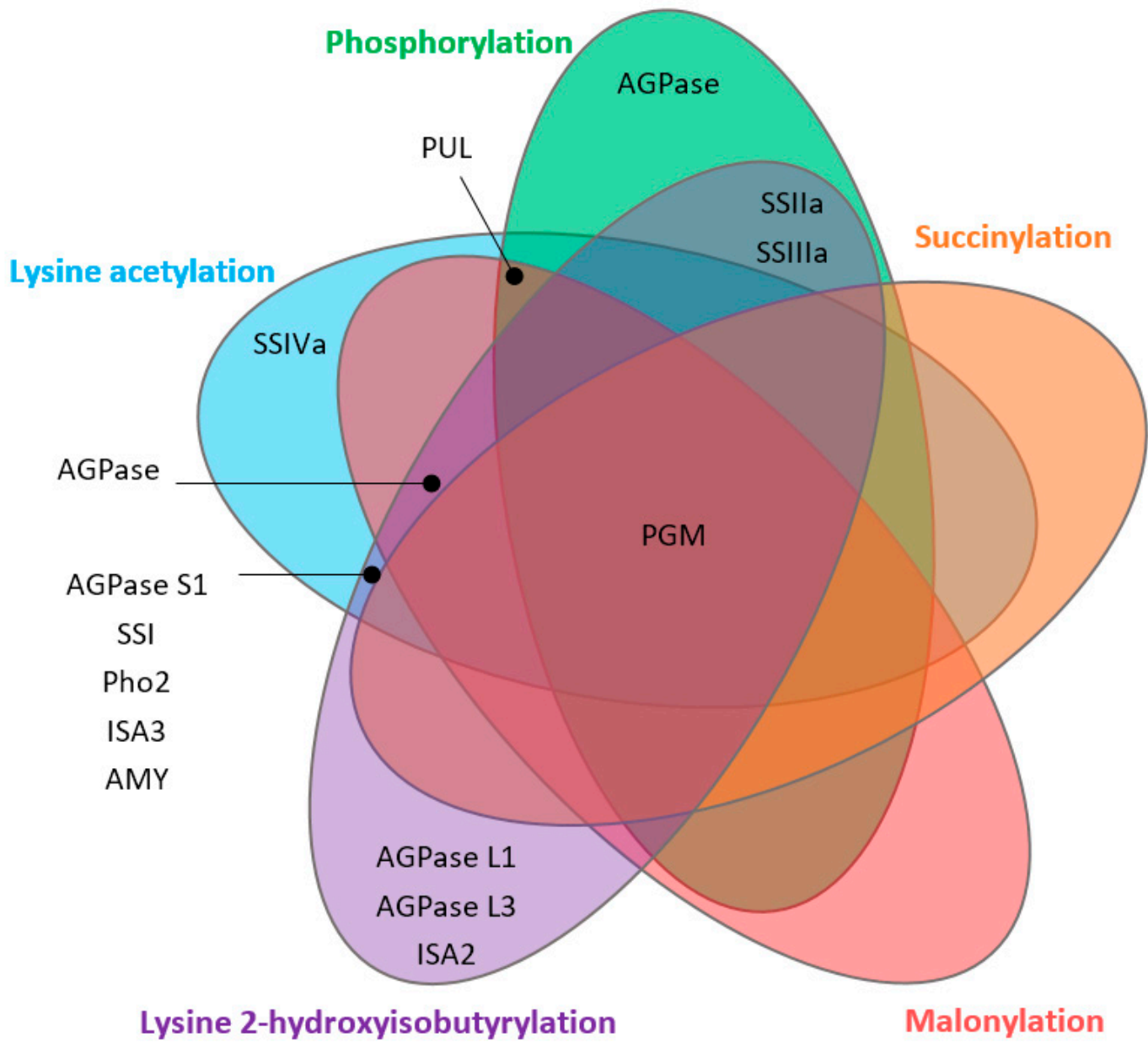

Figure 5. Venn diagram displays the overlap of starch biosynthesis-related proteins targeted by five types of PTMs identified from rice seeds. 


\subsection{Phosphorylation}

\subsubsection{Identification of Phosphorylated Protein in Rice Developing Seeds}

Protein phosphorylation is a reversible process regulated by kinases and phosphatases and regarded as one of the most important PTMs [94]. The studies on phosphorylation have mainly focused on phosphorylation and/or dephosphorylation of specific proteins or protein families in particular signaling pathways [95]. In eukaryotes, the most common class of phosphorylation is found on serine (S), threonine $(\mathrm{T})$, and tyrosine $(\mathrm{Y})$ residues $[96,97]$ in which the $\gamma$-phosphate group covalently reacts with the hydroxyl group of amino acid side chains by potein kinases [98]. A large scale of phosphosites and phosphoproteins has been identified using phosphoproteomic technologies in many cereals such as rice $[27,28,31,99-103]$, wheat [104-108], barley [109,110], and maize [111-115]. Phosphoserine $(>90 \%)$ is a major phosphorylation type of rice endosperm, followed by phosphothreonine $(6-9 \%)$ and phosphotyrosine $(0.1-0.4 \%)$ [28,31]. Nakagami et al. [116] estimated that the proportion of phosphotyrosine in rice is equivalent to that in Arabidopsis and humans.

Recently, the phosphoproteins involved in starch biosynthesis of indica rice cultivars (9311 and Guangluai4) including AGPase (three sites) AGPS2 (five sites), SSIIa (one site), SSIIIa (one site), BEI (four sites), BEIIb (two sites), PUL (three sites) and Pho1 (two sites) were reported by Pang et al. [28] (Table 4).

Table 4. List of identified phosphoproteins involving in starch biosynthesis in rice endosperm based on phosphoproteomics.

\begin{tabular}{|c|c|c|c|c|}
\hline Phosphorylated Protein & Uniprot ACCN & Identified Phosphosite(s) $^{a}$ & Subspecies & Reference \\
\hline \multirow{4}{*}{ AGPase } & \multirow{2}{*}{ B8XEC3 } & S62, S381 & indica & {$[28]$} \\
\hline & & T68 & japonica and indica & {$[28,31]$} \\
\hline & A2Y7W1 & S491 & japonica & [27] \\
\hline & - & - & indica & {$[87,88]$} \\
\hline \multirow{2}{*}{ AGPS2 } & \multirow{2}{*}{ D4AIA3 } & $\mathrm{S} 13$ & japonica and indica & {$[28,31]$} \\
\hline & & $\mathrm{S} 17, \mathrm{~S} 22, \mathrm{~S} 35, \mathrm{~S} 36$ & Indica & {$[28]$} \\
\hline GBSSI & - & - & indica & [87] \\
\hline SSIIa & P0C586 & S126 & indica & {$[28]$} \\
\hline SSIIIa & Q6Z1D6 & S96 & japonica and indica & {$[28,31]$} \\
\hline BEI & D0TZI4 & S562, S620, S814, S815 & indica & {$[28]$} \\
\hline BEIIb & $\mathrm{A} 2 \mathrm{X} 5 \mathrm{~K} 0$ & $\mathrm{~S} 685, \mathrm{~S} 715$ & indica & [28] \\
\hline PUL & D0TZH1 & S154, S155, S869 & indica & [28] \\
\hline \multirow[t]{2}{*}{ Pho1 } & Q9AUV8 & S494, S645 & indica & [28] \\
\hline & Q9AUQ4 & S124 & japonica & [31] \\
\hline \multirow[t]{2}{*}{ PGM } & Q33AE4 & S167 & japonica & [31] \\
\hline & - & - & indica & [88] \\
\hline
\end{tabular}

${ }^{a} \mathrm{~S}$ and $\mathrm{T}$ indicate the phosphorylated site on serine and threonine residues, respectively.

Interestingly, one phosphopeptide of both AGPase and SSIIIa showed consistency between japonica and indica rice [28,31]. AGPase and GBSS were detected as downregulated phosphoproteins during grain-filling stages of inferior spikelets, as compared to superior spikelets [87]. Moreover, PGM and AGPase were differentially phosphorylated between the superior and inferior spikelets in which the expression levels of those phosphoproteins of 10 DAF inferior spikelets were lower than both 1 DAF superior spikelets and 20 DAF inferior spikelets [88].

\subsubsection{Potential Role of Protein Phosphorylation in Starch Biosynthesis}

In amyloplasts, starch biosynthesis isozymes have been demonstrated to display as a complex form (or protein-protein interactions), especially through the regulation of phosphorylation [117-120]. In wheat (Triticum aestivum), phosphorylation can activate SBEIIa and SBEIIb enzymes contributed to the protein complex forming of SBEIIa, SBEIIb, and Pho1 at 12-25 days after pollination (DAP) [117]. On the other hand, dephosphorylation reduces the catalytic activities and breaks the complex formation [117]. Furthermore, the 
phosphorylation-dependent complexes of wheat SSI, SSIIa, and either SBEIIa or SBEIIb were identified in amyloplast at 10-15 DAP [119].

In maize (Zea mays L.) endosperm, SSI, SSIIa, and SBEIIb form a trimeric complex in which SBEIIb is phosphorylated [121]. The complex formation is activated by ATP and disassembled by alkaline phosphatase $[118,121]$. Loss of SBEIlb activity (amylose extender, $a e^{-}$mutant) impacts the protein-protein interactions among SSI, SSIIa, and SBEIIb complex, which is formed in wild type [118]. It was reported that SSI and SSIIa formed the complex possibly through SBEI, SBEIIa, and Pho in the $a e^{-}$mutant. Since the SBEIIb is replaced by SBEI, a reduction of branch points with longer glucan chains was observed in $a e^{-}$ mutant, as compared to the wild type [118,121]. Recently, the phosphorylated SSIIa is reported that to have interactions with SSI and SBEIIb [120]. In addition, in barley (Hordeum vulgare), protein complex formation of SBEIIa, SBEIIb, SSIIa, and SSIIIa was increased by the presence of ATP [122].

In rice endosperm, phosphorylation and dephosphorylation affected the oligomerization and activity of OsGBSSI [123]. The dissociation of OsGBSSI was detected during the phosphatase treatment. The monomer of OsGBSSI increased from 0.07 to $0.86 \%$, and the OsGBSSI activity decreased from 0.17 to $0.11 \mathrm{~mol} / \mathrm{g} / \mathrm{min}$ based upon the increasing phosphatase levels [123]. In addition, GBSSI expression at low temperatures was regulated by phosphorylation [124].

Protein complex formations among starch biosynthesis proteins have been established in rice including the interactions of SSs-SBEs, among SBE isoforms, BEIIa-Pho1, PULBEI [125-127], PUL-BEIIb [126], Pho1-Dpe1 [128], and SSI-SSIIa-BEIIb [126]. Recently, an inactive BEIIb forming a complex with SSI, SSIIa, SSIVb, BEI, and BEIIa was reported [126]. Although the evidence of phosphorylation-dependent complex assembly in rice has not been uncovered, the enzymatic activities and enzymatic complexes in rice might be regulated by phosphorylation, as reported in other cereals.

Taken together, phosphorylation is essential for the regulation of starch biosynthesis and has significant effects on enzymatic activities, complex components, and proteinprotein interactions. Knockout of one enzyme may lead to changes in protein complex formation, other enzyme activities, and amylopectin structure.

\subsection{Lysine Acetylation}

Lysine acetylation, a highly conserved PTM in organisms, is well known for the regulation of transcription [129] and reported in a large number of proteins in many biological processes of organisms [130]. Lysine acetylation is a reversible reaction in which an acetyl group $\left(\mathrm{CH}_{3} \mathrm{Co}\right)$ from acetyl-coenzyme $\mathrm{A}(\mathrm{CoA})$ is donated to $\mathrm{N}^{\varepsilon}$-terminal amine of a lysine residue through acetyltransferases and removed by deacetylases [131]. The acetylation controls the enzymatic activities of metabolic enzymes and alters the metabolic flux profiles [132]. In rice seeds, starch biosynthesis proteins targeted by lysine acetylation were listed in Table 5.

Table 5. List of lysine acetylation and succinylation on starch biosynthesis proteins from rice seeds.

\begin{tabular}{|c|c|c|c|c|c|c|}
\hline $\begin{array}{l}\text { Acetylated } \\
\text { Protein }\end{array}$ & $\begin{array}{l}\text { Uniprot } \\
\text { ACCN }\end{array}$ & $\begin{array}{l}\text { Acetylation } \\
\text { Position }\end{array}$ & Modified Peptide a & Lysine Motif $^{\mathbf{b}}$ & Tissue-Specific $^{b}$ & Reference \\
\hline AGPase S1 & Q69T99 & 203 & MDYQK(ac)FIQAHR & - & - & [30] \\
\hline \multirow[b]{2}{*}{ AGPase S2 } & \multirow[b]{2}{*}{ P15280 } & 217 & MDYEK(ac)FIQAHR & - & $\begin{array}{l}\text { starch granule/seeds } \\
(7 \mathrm{DAP}) / \text { seeds (15 DAF) }\end{array}$ & {$[32] /[30] /[33]$} \\
\hline & & 261 & IVEFAEK(ac)PK & $\underline{\mathrm{KF}}$ & $\begin{array}{l}\text { starch granule/seeds } \\
\text { (unpollinated pistil and } \\
7 \mathrm{DAP}) / \text { seeds (15 DAF) }\end{array}$ & {$[32] /[30] /[33]$} \\
\hline \multirow{4}{*}{ AGPase L2 } & \multirow{4}{*}{ Q5VNT5 } & 250 & ASDYGLVK(ac)FDDSGR & $\underline{K F}$ & $\begin{array}{l}\text { starch granule/seeds ( } 3 \text { and } \\
7 \text { DAP)/seeds (15 DAF) }\end{array}$ & {$[32] /[30] /[33]$} \\
\hline & & 260 & VIAFSEK(ac)PK & - & starch granule & [32] \\
\hline & & 310 & DVLLDILK(ac)SK & - & Seeds (7 DAP) & [30] \\
\hline & & 312 & SK(ac)YAHLQDFGSEILPR & - & Seeds (7 DAP) & [30] \\
\hline
\end{tabular}


Table 5. Cont.

\begin{tabular}{|c|c|c|c|c|c|c|}
\hline $\begin{array}{c}\text { Acetylated } \\
\text { Protein }\end{array}$ & $\begin{array}{l}\text { Uniprot } \\
\text { ACCN }\end{array}$ & $\begin{array}{l}\text { Acetylation } \\
\text { Position }\end{array}$ & Modified Peptide ${ }^{a}$ & Lysine Motif $^{b}$ & Tissue-Specific $^{b}$ & Reference \\
\hline \multirow{2}{*}{ GBSSI } & \multirow{2}{*}{ Q0DEV5 } & 444 & KFEK(ac)LLK & - & starch granule/seeds (15 DAF) & {$[32] /[33]$} \\
\hline & & 452 & SMEEK(ac)YPGK & $\underline{\mathrm{K} Y}$ & starch granule/seeds (15 DAF) & [32]/[33] \\
\hline SSI & Q0DEC8 & 193 & NFANAFYTEK(ac)HIK & - & seeds ( 3 and 7 DAP) & [30] \\
\hline SSIVa & Q5JMA0 & 589 & AQYYGEHDDFK(ac)R & - & seeds (15 DAF) & [33] \\
\hline \multirow{10}{*}{ SBEI } & \multirow{10}{*}{ Q0D9D0 } & 89 & LEEFK(ac)DHFNYR & - & starch granule/seeds (15 DAF) & {$[32] /[33]$} \\
\hline & & 103 & YLDQK(ac)CLIEK & - & starch granule/seeds (15 DAF) & [32]/[33] \\
\hline & & 118 & HEGGLEEFFSK(ac)GYLK & KXXXK & starch granule/seeds (15 DAF) & [32]/[33] \\
\hline & & 164 & DK(ac)FGIWSIK & $\underline{\mathrm{KF}}$ & starch granule/seeds (15 DAF) & {$[32] /[33]$} \\
\hline & & 236 & YVFK(ac)HPR & $\underline{\overline{\mathrm{K}}} \mathrm{H}$ & starch granule/seeds (15 DAF) & [32]/[33] \\
\hline & & 372 & GYHK(ac)LWDSR & $\underline{K X X X X R}$ & starch granule/seeds (15 DAF) & {$[32] /[33]$} \\
\hline & & 614 & EGNNWSYDK(ac)CR & - & starch granule/seeds (15 DAF) & {$[32] /[33]$} \\
\hline & & 662 & QIVSDMNEK(ac)DK & - & starch granule/seeds (15 DAF) & {$[32] /[33]$} \\
\hline & & 697 & VGCDLPGK(ac)YR & $\underline{\mathrm{KY}}$ & starch granule/seeds (15 DAF) & {$[32] /[33]$} \\
\hline & & 809 & GM(ox)K(ac)FVFR & $\underline{K X X X R}$ & starch granule/seeds (15 DAF) & {$[32] /[33]$} \\
\hline \multirow{6}{*}{ SBEIIb } & \multirow{6}{*}{ Q6H6P8 } & 134 & VVEELAAEQK(ac)PR & - & seeds $(15 \mathrm{DAF})$ & [33] \\
\hline & & 303 & YIFK(ac)HPQPK & $\underline{\mathrm{K}} \mathrm{H}$ & Seed (7 DAP)/seeds (15 DAF) & {$[30] /[33]$} \\
\hline & & 587 & WSEK(ac)CVTYAESHDQALVGDK & - & $\begin{array}{c}\text { seeds (unpollinated pistil and } \\
7 \mathrm{DAP} \text { ) }\end{array}$ & {$[30]$} \\
\hline & & 688 & FIPGNNNSYDK(ac)CR & - & seeds $(7 \mathrm{DAP})$ & [30] \\
\hline & & 738 & KHEEDK(ac)MIIFEK & - & starch granule/seeds (15 DAF) & {$[32] /[33]$} \\
\hline & & 771 & VGCLKPGK(ac)YK & $\underline{\mathrm{K}}$ & starch granule/seeds (15 DAF) & {$[32] /[33]$} \\
\hline ISA3 & Q6K4A4 & 130 & K(ac)YFGVAEEK & $\underline{\mathrm{KY}}$ & seeds (15 DAF) & [33] \\
\hline PUL & Q7X834 & 805 & NEENWHLIK(ac)PR & - & seeds (15 DAF) & [33] \\
\hline \multirow{10}{*}{ PMG } & \multirow{10}{*}{ Q9AUQ4 } & 8 & VLFSVTK(su)K & - & embryos (24 HAI) & [34] \\
\hline & & 18 & ATTPFDGQK(ac)PGTSGLR & - & $\begin{array}{l}\text { embryos (24 HAI)/seeds } \\
\text { (15 DAF) }\end{array}$ & {$[34] /[33]$} \\
\hline & & & ATTPFDGQK(su)PGTSGLR & & embryos (24 HAI) & [34] \\
\hline & & 69 & YFSK(ac)DAVQIITK & - & embryos (24 HAI) & [34] \\
\hline & & 206 & LMK $(\mathrm{ac})$ TIFDFESIK & - & embryos (24 HAI) & [34] \\
\hline & & 215 & TIFDFESIK(ac)K & - & seeds (15 DAF) & [33] \\
\hline & & 275 & EDFGGGHPDPNLTYAK(ac)ELVDR & - & embryos (24 HAI) & [34] \\
\hline & & 361 & NLNLK(ac)FFEVPTGWK & - & embryos (24 HAI) & [34] \\
\hline & & 506 & DPVDGSVSK(ac)HQGVR & $\underline{\mathrm{KH}}$ & $\begin{array}{c}\text { embryos (24 HAI)/seeds } \\
\text { (15 DAF) }\end{array}$ & {$[34] /[33]$} \\
\hline & & 543 & VYIEQYEK(ac)DSSK & $\underline{K} X X X K$ & seeds (15 DAF) & [33] \\
\hline \multirow{7}{*}{$\mathrm{PhoH}$} & \multirow{7}{*}{ Q8LQ33 } & 169 & YGLFK(ac)QCITK & - & embryos (24 HAI) & [34] \\
\hline & & 409 & HMEIIEEIDK(ac)R & - & embryos (24 HAI) & [34] \\
\hline & & 412 & FK(su)EMVISTR & - & embryos (24 HAI) & [34] \\
\hline & & 439 & ILDNSNPQK(su)PVVR & - & embryos (24 HAI) & [34] \\
\hline & & 645 & LVNDVGAVVNNDPDVNK(ac)YLK & - & embryos (24 HAI) & [34] \\
\hline & & 747 & FEEAK $(\mathrm{ac}) \mathrm{QLIR}$ & KXXXR & seeds (15 DAF) & [33] \\
\hline & & 818 & MSILNTAGSGK(ac)FSSDR & - & embryos (24 HAI) & [34] \\
\hline \multirow{9}{*}{ PhoL } & \multirow{9}{*}{ Q9AUV8 } & 216 & YK(ac)HGLFK & $\underline{\mathrm{K}} \mathrm{H}$ & $\begin{array}{c}\text { starch granule/seeds } \\
\text { (unpollinated pistil, } 3 \text { DAP } \\
\text { and } 7 \text { DAP)/seeds (15 DAF) }\end{array}$ & {$[32] /[30] /[33]$} \\
\hline & & 255 & TDVSYPVK(ac)FYGK & KXXXK & starch granule/seeds (15 DAF) & {$[32] /[33]$} \\
\hline & & 451 & YGTEDTSLLK $(\mathrm{ac}) \mathrm{K}$ & - & starch granule/seeds (15 DAF) & {$[32] /[33]$} \\
\hline & & 504 & SLEPSVVVEEK(ac)TVSK & $\underline{K X X X K}$ & starch granule/seeds (15 DAF) & {$[32] /[33]$} \\
\hline & & 594 & FQNK(ac)TNGVTPR & -- & starch granule/seeds (15 DAF) & [32]/[33] \\
\hline & & 734 & AFATYVQAK(ac)R & - & seeds (7 DAP) & [30] \\
\hline & & 846 & AQGK(ac)FVPDPR & $\underline{\mathrm{KF}}$ & starch granule/seeds (15 DAF) & {$[32] /[33]$} \\
\hline & & 913 & DQK $(\mathrm{ac})$ LWTR & KXXXR & starch granule/seeds (15 DAF) & {$[32] /[33]$} \\
\hline & & 928 & MSILNTASSSK(ac)FNSDR & $\underline{\mathrm{KF}}$ & starch granule/seeds (15 DAF) & [32] \\
\hline \multirow{4}{*}{ AMY } & \multirow{2}{*}{ Q0J528 } & 88 & LYDLDASK(ac)YGTEAELK & - & embryos (24 HAI)/- & [34] \\
\hline & & 123 & CADYK(ac)DSR & - & - & [30] \\
\hline & \multirow{2}{*}{ P27933 } & 88 & LYDLDASK(ac)YGTAAELK & - & - & [30] \\
\hline & & 215 & GYSTDIAK(ac)MYVESCK & - & - & [30] \\
\hline
\end{tabular}

${ }^{\mathrm{a}}$ (ac) and (su) indicate the acetylation and succinylation sites on lysine, respectively. ${ }^{\mathrm{b}} \underline{\mathrm{K}}$ is the position of the acetylated or succinylated lysine, and $X$ refers to a random amino acid residue. 
In total, 2, 2, 2, 10, 2, and 8 sites of lysine acetylation modifications identified from starch granules of mature rice endosperm were reported for AGPase S2, AGPase L2, GBSSI, SBEI, SBEIIb, and Pho L, respectively [32] (Table 5). PGM, Pho L, and AMY were acetylated with six, four, and one sites at the early stage of rice seed germination ( $24 \mathrm{~h}$ after imbibition) [34]. In addition, Wang et al. [30] reported the largest acetylome based on three different developing stages of rice seeds (unpollinated pistil, 3 DAP, and 7 DAP) covering 1817 acetylsites from 972 acetylproteins. Seven starch biosynthesis proteins were targeted by acetyllysine including AGPase S1 (one site), AGPase S2 (two sites), AGPase L2 (three sites), AMY (four sites), SBE3 (three sites), Pho L (two sites), and SSI (one site) (Table 5).

Compared to root, leave, flower, and pollen, the prominent acetylated proteins of rice were observed in seeds at 7,15, and 21 DAF, as well as in mature dry seeds [33]. A total of 1003 acetylated sites on 692 proteins were identified from rice seeds at 15 DAF [33]. Interestingly, 11 starch biosynthesis proteins were lysine-acetylated including AGPasae S2, AGPasae L2, GBSSI, SSIVa, SBEI, SBEIIb, ISA3, PUL, PMG, Pho H, and Pho L (Table 5).

Among those acetylated proteins, SBEI and Pho L were heavily acetylated on 10 and 8 sites, respectively, which were in a similar result of starch granule acetylome [32]. Out of 7 distinguished motifs of acetylation site reported by Meng et al. [33], 6 motifs displayed amongst the 11 acetylated starch biosynthesis proteins including $\underline{\mathrm{KF}}(5), \underline{\mathrm{K} Y}(4), \underline{\mathrm{K} X X X R}(3)$, KXXXXR (1), KXXXK (4) and KH (4) (Table 5).

Lysine acetylation has a strong impact on the biochemical functions of proteins [133]. For example, Ribulose-15-bisphosphate carboxylase/oxygenase (Rubisco) activity was decreased by lysine acetylation [134], the increased glyceraldehyde-3-phosphate dehydrogenases (GAPDH) acetylation in leaves of Brachypodium distachyon L. enhanced the activity in glycolysis and decreased the activity in gluconeogenesis [135]. On the other hand, de-acetylation can increase the pyruvate orthophosphate dikinase (PPDK) activity in maize after $12 \mathrm{~h}$ of illumination with white light [134]. It is plausible that lysine acetylation may influence the catalytic activities of starch biosynthesis proteins in rice.

\subsection{Succinylation}

Succinylation is recently identified as one of the PTMs on lysine residue [136,137] and plays an important role in gene transcription, cellular metabolism, DNA damage response [138], and plant growth [135]. Zhang et al. [136] reported that succinyl-CoA plays a role as a cofactor for lysine succinylation. Among 261 acetylated proteins identified in rice embryos at $24 \mathrm{~h}$ after imbibition, two sites from both PGM (8 and 18) and Pho H (412 and 439) were succinylated, which might be involved in the metabolism regulation [34]. Lysine residue at 18 positions on PGM (Uniprot: Q9AUQ4) was targeted for both acetylation and succinylation modifications (Table 5).

Previous studies indicated that succinylation has a potential impact on protein structure and functions [136] as well as cellular processes [139]. Succinylation alters the electrophoretic mobility and isoionic $\mathrm{pH}$ of ovalbumin [140], inactivates the canonical carnitine palmitoyltransferase (CPTase) activity, decreases the enolase activity [141], and promotes cell invasion and migration [139]. Succinylation in plants has been reported in rice [34], tomato [142], B. distachyon L. [135], patchouli [143], and tea [144]. However, the effect of lysine succinylation in plants is relatively limited.

\subsection{Lysine 2-Hydroxyisobutyrylation $\left(K_{\text {hib }}\right)$ and Malonylation $\left(K_{m a l}\right)$}

$\mathrm{K}_{\text {hib }}$ is a highly dynamic PTM found on both histone and nonhistone proteins affecting the histone-DNA association and playing role in diverse biological processes $[36,145]$. $K_{\text {hib }}$ introduces a huge change in size, as compared to lysine acetylation, and particularly forms hydrogen bonds with other molecules via its hydroxyl group [145].

In contrast, $\mathrm{K}_{\mathrm{mal}}$, a lately identified lysine acylation, is evolutionarily conserved in mammalian and bacteria cells [146,147] and responsible for the regulation of cellular mechanisms and activities $[35,146] . \mathrm{K}_{\text {mal }}$ triggers more dramatic structural changes than both lysine acetylation and methylation on the substrate proteins [147]. Recently, both 
$\mathrm{K}_{\text {hib }}$ and $\mathrm{K}_{\mathrm{mal}}$ were identified from the developing rice seeds at 15 DAF reported by Meng et al. [36] and Mujahid [35], respectively (Table 6).

Table 6. Summary of lysine 2-hydroxyisobutyrylation $\left(\mathrm{K}_{\mathrm{hib}}\right)$ and malonylation $\left(\mathrm{K}_{\mathrm{mal}}\right)$ on starch biosynthesis proteins from 15 DAF developing rice seeds identified by Meng et al. [36] and Mujahid et al. [35], respectively.

\begin{tabular}{|c|c|c|c|}
\hline Protein & Uniprot ACCN & No. of $K_{\text {hib }}$ and $K_{\text {mal }}{ }^{*}$ & Position \\
\hline AGPase S1 & Q69T99 & 5 & $203,234,249,442,462$ \\
\hline \multirow[t]{2}{*}{ AGPase S2 } & \multirow[t]{2}{*}{ P15280 } & 19 & $\begin{array}{c}102,132,217,239,248,261,263,268,285,360,385,403,406,441, \\
447,456,467,476,496\end{array}$ \\
\hline & & $3 *$ & $106,360,403$ \\
\hline AGPase L1 & Q6AVT2 & 11 & $100,194,196,247,299,331,326,369,446,456,470$ \\
\hline \multirow[t]{2}{*}{ AGPase L2 } & \multirow[t]{2}{*}{ Q5VNT5 } & 21 & $\begin{array}{c}37,74,187,223,250,263,273,286,301,302,310,312,334,364 \\
371,392,425,443,449,459,504\end{array}$ \\
\hline & & $4 *$ & $250,312,371,449$ \\
\hline AGPase L3 & Q688T8 & 4 & $202,228,315,376$ \\
\hline GBSSI & Q0DEV5 & 8 & $181,192,309,381,385,530,538,549$ \\
\hline SSI & Q0DEC8 & 8 & $193,196,349,357,429,461,467,570$ \\
\hline SSII-3 & Q0DDE3 & 5 & $151,244,346,378,532$ \\
\hline SSIIIa & Q6Z1D6 & 8 & $228,649,761,794,808,961,1203,1604$ \\
\hline \multirow[t]{2}{*}{ SBEI } & \multirow[t]{2}{*}{ Q0D9D0 } & 33 & $\begin{array}{c}62,64,84,89,103,108,118,122,157,164,171,186,215,236,319, \\
324,372,423,500,506,524,540,549,614,662,664,683,689,697 \\
744,775,796,809\end{array}$ \\
\hline & & $6 *$ & $108,118,506,524,689,809$ \\
\hline \multirow[t]{2}{*}{ SBEIIb } & \multirow[t]{2}{*}{ Q6H6P8 } & 22 & $\begin{array}{c}134,146,158,191,231,268,299,328,386,466,558,564,571,587, \\
603,612,636,677,688,719,738,773,\end{array}$ \\
\hline & & $1 *$ & 719 \\
\hline \multirow{2}{*}{ AMY } & Q0J528 & 5 & $39,88,105,207,262$ \\
\hline & Q0JJV2 & 1 & 88 \\
\hline ISA2 & Q6AU80 & 2 & 319,369 \\
\hline ISA3 & Q6K4A4 & 2 & 266,269 \\
\hline $\mathrm{PhoH}$ & Q8LQ33 & 8 & $115,409,425,533,542,595,721,818$ \\
\hline \multirow[t]{2}{*}{ PhoL } & \multirow[t]{2}{*}{ Q9AUV8 } & 32 & $\begin{array}{c}134,255,259,277,289,356,381,410,418,429,441,451,471,493, \\
504,590,617,630,636,657,665,681,725,734,738,846,893,904, \\
913,928,940,946,\end{array}$ \\
\hline & & $3 *$ & $259,493,657$ \\
\hline PUL & Q7X834 & $2 *$ & 274,871 \\
\hline \multirow{2}{*}{ PGM } & Q33AE4 & 7 & $61,67,118,413,492,584,595$ \\
\hline & Q9AUQ4 & $3 *$ & $54,458,568$ \\
\hline
\end{tabular}

A total of $2512 \mathrm{~K}_{\text {hib }}$ proteins were reported in rice [36] and amongst those proteins, 17 proteins involving in starch biosynthesis were targeted (Table 6). The highest modified sites of $K_{\text {hib }}$ were observed on SBEI (33 sites), followed by Pho L (32 sites) and AGPase L2 (21 sites). The $\mathrm{K}_{\mathrm{hib}}$ function on targeted proteins remains unknown in rice. However, there was evidence that $K_{\text {hib }}$ modification may introduce the conformational changes of Enolase1 and alter the substrate binding [148]. $\mathrm{K}_{\text {hib }}$ increased the hydrophobic solvent-accessible surface area and decreased the enzymatic activity of UvSlt2 [149]. 
For $\mathrm{K}_{\mathrm{mal}}$, seven starch biosynthesis proteins out of 247 malonylated proteins were reported [35]. The number of the modified sites of AGPase S2, AGPase L2, SBEI, SBEIIb, Pho L, PUL, and PGM was 3, 4, 6, 1, 3, 2, 3, respectively (Table 6). Although malonylation can occur on several enzymes of the starch biosynthesis mechanism, the potential roles of $\mathrm{K}_{\text {mal }}$ remain largely unknown. The malonylation has an important role in the enzymatic activity of various proteins. For example, the enzymatic activity of malonylated fructose bisphosphate aldolase B (ALDOB) was decreased by $20 \%$, as compared to nonmalonylated ALDOB [150]. Malonylation increased the enzymatic activity of glyceraldehyde-3-phosphate dehydrogenase (GAPDH) and also interrupted its binding to the target mRNAs [151]. Moreover, cells with elevated $\mathrm{K}_{\mathrm{mal}}$ had the impaired mitochondrial function and fatty acid oxidation [152].

\section{Summary and Future Perspectives}

Even though identification of the proteomics and PTMs has been conducted in rice developing seeds, there still remain significant gaps in their regulations in starch biosynthesis. This review presents the significant proteins associated with starch biosynthesis in rice seeds and their expression profiles through different developmental stages and high temperatures. Most of the key proteins in starch biosynthesis are generally increased in the endosperms during 6-20 DAF. SSIIIa and AMY are promising proteins in chalky formation. Hight temperature initiates starch degradation rather than starch biosynthesis and then also results in the reduction of amylose content as well as the increase in chalkiness in rice seeds. Twenty starch biosynthesis proteins are targeted by five types of PTMs including phosphorylation, lysine acetylation, succinylation, lysine 2-hydroxyisobutyrylation, and malonylation. PGM is commonly targeted by all the five PTMs types (Figure 5). Phosphorylation is the most important PTM for starch biosynthesis proteins regarding the regulation of protein complex formation. This information is useful to understand the molecular mechanisms underlying starch biosynthesis, which ultimately affect starch functionality with known and unknown regulatory pathways. Further studies, however, may be focused on the following aspects:

(1) Proteome alteration under climate change environment: Recently, the global population is facing challenging problems caused by global warming and climate change, which have a great impact on rice yield and quality. Further studies are needed to determine the consequences of climate change, e.g., high/low temperatures, carbon dioxide levels, drought stress, etc., on starch biosynthesis mechanism and regulation by using proteomic analysis.

(2) The number and new types of PTMs in rice seeds: Although five types of PTMs were identified from rice seeds, whether there are other PTMs in rice seed has not been fully addressed. For the number of PTMs sites, $K_{\text {hib }}$ showed the highest number of targeted starch biosynthesis proteins (17 proteins), while the lowest number was observed in succinylation (2 proteins). Whether more PTMs would be found under the specific genotype or under the specific abiotic conditions such as heat stress, high carbon dioxide levels, etc., is unknown.

(3) The roles and regulation mechanisms of PTMs on starch biosynthesis: Little is known about the roles of individual PTM on the starch biosynthesis proteins and the impact of PTMs on enzymes' activities, protein-protein interaction (protein complex formation), and starch functionality. The phosphorylation is well reported in protein complex formation during the starch biosynthesis process in the endosperm of cereal crops. Indepth regulatory studies on protein-protein interactions are necessary to understand the role of protein complex formation in starch biosynthesis in different crops.

Author Contributions: Conceptualization, J.B. and P.T.; writing-original draft preparation, P.T., Y.Y. and F.X.; writing - review and editing, P.T. and J.B.; funding acquisition, J.B. All authors have read and agreed to the published version of the manuscript. 
Funding: This work was financially supported by the National Key Research and Development Program of China (Grant No. 2016YFD0400104), the Natural Science Foundation of China (Grant No. 31871531), and Zhejiang Province (LZ21C130003) (for J.B.), and the Postdoctoral InternationaExchange Program (for P.T.).

Institutional Review Board Statement: Not applicable.

Informed Consent Statement: Not applicable.

Data Available Statement: All data presented in this review can be found in the references cited in the text.

Conflicts of Interest: The authors declare no conflict of interest.

\section{References}

1. FAO. FAOSTAT. Available online: http://www.fao.org/home/en (accessed on 8 February 2020).

2. Jiang, C.; Cheng, Z.; Zhang, C.; Yu, T.; Zhong, Q.; Shen, J.Q.; Huang, X. Proteomic analysis of seed storage proteins in wild rice species of the Oryza genus. Proteome Sci. 2014, 12, 51. [CrossRef]

3. Wang, W.; Mauleon, R.; Hu, Z.; Chebotarov, D.; Tai, S.; Wu, Z.; Li, M.; Zheng, T.; Fuentes, R.R.; Zhang, F.; et al. Genomic variation in 3,010 diverse accessions of Asian cultivated rice. Nature 2018, 557, 43-49. [CrossRef]

4. Gutaker, R.M.; Groen, S.C.; Bellis, E.S.; Choi, J.Y.; Pires, I.S.; Bocinsky, R.K.; Slayton, E.R.; Wilkins, O.; Castillo, C.C.; Negrão, S.; et al. Genomic history and ecology of the geographic spread of rice. Nat. Plants 2020, 6, 492-502. [CrossRef]

5. Li, X.; Wu, L.; Wang, J.; Sun, J.; Xia, X.; Geng, X.; Wang, X.; Xu, Z.; Xu, Q. Genome sequencing of rice subspecies and genetic analysis of recombinant lines reveals regional yield- and quality-associated loci. BMC Biol. 2018, 16, 102. [CrossRef]

6. Khush, G.S. Origin, dispersal, cultivation and variation of rice. Plant Mol. Biol. 1997, 35, 25-34. [CrossRef] [PubMed]

7. He, D.; Yang, P. Proteomics of rice seed germination. Front. Plant Sci. 2013, 4, 246. [CrossRef] [PubMed]

8. Kim, Y.J.; Choi, S.H.; Park, B.S.; Song, J.T.; Kim, M.C.; Koh, H.J.; Seo, H.S. Proteomic analysis of the rice seed for quality improvement. Plant Breed. 2009, 128, 541-550. [CrossRef]

9. Goren, A.; Ashlock, D.; Tetlow, I.J. Starch formation inside plastids of higher plants. Protoplasma 2018, 255, 1855-1876. [CrossRef]

10. Zeeman, S.C.; Kossmann, J.; Smith, A.M. Starch: Its metabolism, evolution, and biotechnological modification in plants. Annu. Rev. Plant Biol. 2010, 61, 209-234. [CrossRef]

11. Ball, S.G.; Morell, M.K. From bacterial glycogen to starch: Understanding the biogenesis of the plant starch granule. Annu. Rev. Plant Biol. 2003, 54, 207-233. [CrossRef] [PubMed]

12. Jobling, S. Improving starch for food and industrial applications. Curr. Opin. Plant Biol. 2004, 7, 210-218. [CrossRef] [PubMed]

13. Lin, S.K.; Chang, M.C.; Tsai, Y.G.; Lur, H.S. Proteomic analysis of the expression of proteins related to rice quality during caryopsis development and the effect of high temperature on expression. Proteomics 2005, 5, 2140-2156. [CrossRef]

14. Kawagoe, Y.; Kubo, A.; Satoh, H.; Takaiwa, F.; Nakamura, Y. Roles of isoamylase and ADP-glucose pyrophosphorylase in starch granule synthesis in rice endosperm. Plant J. 2005, 42, 164-174. [CrossRef]

15. Fujita, N.; Yoshida, M.; Asakura, N.; Ohdan, T.; Miyao, A.; Hirochika, H.; Nakamura, Y. Function and characterization of starch synthase I using mutants in rice. Plant Physiol. 2006, 140, 1070-1084. [CrossRef]

16. Thurston, G.; Regan, S.; Rampitsch, C.; Xing, T. Proteomic and phosphoproteomic approaches to understand plant-pathogen interactions. Physiol. Mol. Plant. Pathol. 2005, 66, 3-11. [CrossRef]

17. Cánovas, F.M.; Dumas-Gaudot, E.; Recorbet, G.; Jorrin, J.; Mock, H.-P.; Rossignol, M. Plant proteome analysis. Proteomics 2004, 4 , 285-298. [CrossRef] [PubMed]

18. Newton, R.P.; Brenton, A.G.; Smith, C.J.; Dudley, E. Plant proteome analysis by mass spectrometry: Principles, problems, pitfalls and recent developments. Phytochemistry 2004, 65, 1449-1485. [CrossRef]

19. Lin, Z.; Zhang, X.; Yang, X.; Li, G.; Tang, S.; Wang, S.; Ding, Y.; Liu, Z. Proteomic analysis of proteins related to rice grain chalkiness using iTRAQ and a novel comparison system based on a notched-belly mutant with white-belly. BMC Plant Biol. 2014, 14, 163. [CrossRef]

20. Wittmann-Liebold, B.; Graack, H.-R.; Pohl, T. Two-dimensional gel electrophoresis as tool for proteomics studies in combination with protein identification by mass spectrometry. Proteomics 2006, 6, 4688-4703. [CrossRef]

21. Yang, P.; Li, X.; Wang, X.; Chen, H.; Chen, F.; Shen, S. Proteomic analysis of rice (Oryza sativa) seeds during germination. Proteomics 2007, 7, 3358-3368. [CrossRef]

22. Xu, S.B.; Li, T.; Deng, Z.Y.; Chong, K.; Xue, Y.; Wang, T. Dynamic proteomic analysis reveals a switch between central carbon metabolism and alcoholic fermentation in rice filling grains. Plant. Physiol. 2008, 148, 908-925. [CrossRef] [PubMed]

23. Koller, A.; Washburn, M.P.; Lange, B.M.; Andon, N.L.; Deciu, C.; Haynes, P.A.; Hays, L.; Schieltz, D.; Ulaszek, R.; Wei, J.; et al. Proteomic survey of metabolic pathways in rice. Proc. Natl. Acad. Sci. USA 2002, 99, 11969. [CrossRef]

24. Xu, S.B.; Yu, H.T.; Yan, L.F.; Wang, T. Integrated proteomic and cytological study of rice endosperms at the storage phase. $J$. Proteome Res. 2010, 9, 4906-4918. [CrossRef] [PubMed]

25. Lee, J.; Koh, H.-J. A label-free quantitative shotgun proteomics analysis of rice grain development. Proteome Sci. $2011,9,61$. [CrossRef] 
26. Yu, H.; Wang, T. Proteomic dissection of endosperm starch granule associated proteins reveals a network coordinating starch biosynthesis and amino acid metabolism and glycolysis in rice endosperms. Front. Plant Sci. 2016, 7, 707. [CrossRef]

27. Han, C.; Wang, K.; Yang, P. Gel-based comparative phosphoproteomic analysis on rice embryo during germination. Plant. Cell Physiol. 2014, 55, 1376-1394. [CrossRef]

28. Pang, Y.; Zhou, X.; Chen, Y.; Bao, J.S. Comparative phosphoproteomic analysis of the developing seeds in two Indica rice (Oryza sativa L.) cultivars with different starch quality. J. Agric. Food Chem. 2018, 66, 3030-3037. [CrossRef]

29. Huang, K.-Y.; Su, M.-G.; Kao, H.-J.; Hsieh, Y.-C.; Jhong, J.-H.; Cheng, K.-H.; Huang, H.-D.; Lee, T.-Y. dbPTM 2016: 10-year anniversary of a resource for post-translational modification of proteins. Nucleic Acids Res. 2016, 44, D435-D446. [CrossRef]

30. Wang, Y.; Hou, Y.; Qiu, J.; Li, Z.; Zhao, J.; Tong, X.; Zhang, J. A quantitative acetylomic analysis of early seed development in rice (Oryza sativa L.). Int. J. Mol. Sci. 2017, 18, 1376. [CrossRef] [PubMed]

31. Qiu, J.; Hou, Y.; Tong, X.; Wang, Y.; Lin, H.; Liu, Q.; Zhang, W.; Li, Z.; Nallamilli, B.R.; Zhang, J. Quantitative phosphoproteomic analysis of early seed development in rice (Oryza sativa L.). Plant Mol. Biol. 2016, 90, 249-265. [CrossRef]

32. Xing, S.; Meng, X.; Zhou, L.; Mujahid, H.; Zhao, C.; Zhang, Y.; Wang, C.; Peng, Z. Proteome profile of starch granules purified from rice (Oryza sativa) endosperm. PLoS ONE 2016, 11, e0168467. [CrossRef] [PubMed]

33. Meng, X.; Lv, Y.; Mujahid, H.; Edelmann, M.J.; Zhao, H.; Peng, X.; Peng, Z. Proteome-wide lysine acetylation identification in developing rice (Oryza sativa) seeds and protein co-modification by acetylation, succinylation, ubiquitination, and phosphorylation. Biochim. Biophys. Acta (BBA)-Proteins Proteom. 2018, 1866, 451-463. [CrossRef]

34. He, D.; Wang, Q.; Li, M.; Damaris, R.N.; Yi, X.; Cheng, Z.; Yang, P. Global proteome analyses of lysine acetylation and succinylation reveal the widespread involvement of both modification in metabolism in the embryo of germinating rice seed. J. Proteome Res. 2016, 15, 879-890. [CrossRef]

35. Mujahid, H.; Meng, X.; Xing, S.; Peng, X.; Wang, C.; Peng, Z. Malonylome analysis in developing rice (Oryza sativa) seeds suggesting that protein lysine malonylation is well-conserved and overlaps with acetylation and succinylation substantially. $J$. Proteom. 2018, 170, 88-98. [CrossRef] [PubMed]

36. Meng, X.; Xing, S.; Perez, L.M.; Peng, X.; Zhao, Q.; Redoña, E.D.; Wang, C.; Peng, Z. Proteome-wide analysis of lysine 2-hydroxyisobutyrylation in developing rice (Oryza sativa) seeds. Sci. Rep. 2017, 7, 17486. [CrossRef]

37. Seck, P.A.; Diagne, A.; Mohanty, S.; Wopereis, M.C.S. Crops that feed the world 7: Rice. Food Secur. 2012, 4, 7-24. [CrossRef]

38. Chang, T.-S.; Liu, C.-W.; Lin, Y.-L.; Li, C.-Y.; Wang, A.Z.; Chien, M.-W.; Wang, C.-S.; Lai, C.-C. Mapping and comparative proteomic analysis of the starch biosynthetic pathway in rice by 2D PAGE/MS. Plant Mol. Biol. 2017, 95, 333-343. [CrossRef]

39. Bao, J.S. Biotechnology for rice grain quality improvement. In Rice Chemistry and Technology, 4th ed.; Bao, J.S., Ed.; Elsevier: Amsterdam, The Netherlands, 2019; pp. 443-471. [CrossRef]

40. Akihiro, T.; Mizuno, K.; Fujimura, T. Gene expression of ADP-glucose pyrophosphorylase and starch contents in rice cultured cells are cooperatively regulated by sucrose and ABA. Plant Cell Physiol. 2005, 46, 937-946. [CrossRef]

41. Hannah, L.C.; James, M. The complexities of starch biosynthesis in cereal endosperms. Curr. Opin. Biotechnol. 2008, 19, 160-165. [CrossRef]

42. Nakamura, Y.; Francisco, P.B.; Hosaka, Y.; Sato, A.; Sawada, T.; Kubo, A.; Fujita, N. Essential amino acids of starch synthase IIa differentiate amylopectin structure and starch quality between japonica and indica rice varieties. Plant Mol. Biol. 2005, 58, 213-227. [CrossRef]

43. Fujita, N.; Yoshida, M.; Kondo, T.; Saito, K.; Utsumi, Y.; Tokunaga, T.; Nishi, A.; Satoh, H.; Park, J.-H.; Jane, J.-L.; et al. Characterization of SSIIIa-deficient mutants of rice: The function of SSIIIa and pleiotropic effects by SSIIIa deficiency in the rice endosperm. Plant Physiol. 2007, 144, 2009-2023. [CrossRef]

44. Ohdan, T.; Francisco, P.B., Jr.; Sawada, T.; Hirose, T.; Terao, T.; Satoh, H.; Nakamura, Y. Expression profiling of genes involved in starch synthesis in sink and source organs of rice. J. Exp. Bot. 2005, 56, 3229-3244. [CrossRef]

45. Hirose, T.; Terao, T. A comprehensive expression analysis of the starch synthase gene family in rice (Oryza sativa L.). Planta 2004, 220, 9-16. [CrossRef]

46. Pfister, B.; Zeeman, S.C. Formation of starch in plant cells. Cell Mol. Life Sci. 2016, 73, 2781-2807. [CrossRef]

47. Nakamura, Y. Towards a better understanding of the metabolic system for amylopectin biosynthesis in plants: Rice endosperm as a model tissue. Plant Cell Physiol. 2002, 43, 718-725. [CrossRef]

48. Zhu, L.; Gu, M.; Meng, X.; Cheung, S.C.K.; Yu, H.; Huang, J.; Sun, Y.; Shi, Y.; Liu, Q. High-amylose rice improves indices of animal health in normal and diabetic rats. Plant. Biotechnol. J. 2012, 10, 353-362. [CrossRef]

49. Nakamura, Y.; Utsumi, Y.; Sawada, T.; Aihara, S.; Utsumi, C.; Yoshida, M.; Kitamura, S. Characterization of the reactions of starch branching enzymes from rice endosperm. Plant. Cell Physiol. 2010, 51, 776-794. [CrossRef]

50. Fujita, N.; Toyosawa, Y.; Utsumi, Y.; Higuchi, T.; Hanashiro, I.; Ikegami, A.; Akuzawa, S.; Yoshida, M.; Mori, A.; Inomata, K.; et al. Characterization of pullulanase (PUL)-deficient mutants of rice (Oryza sativa L.) and the function of PUL on starch biosynthesis in the developing rice endosperm. J. Exp. Bot. 2009, 60, 1009-1023. [CrossRef]

51. Hwang, S.-K.; Koper, K.; Okita, T.W. The plastid phosphorylase as a multiple-role player in plant metabolism. Plant Sci. 2020, 290, 110303. [CrossRef]

52. Van Berkel, J.; Conrads-Strauch, J.; Steup, M. Glucan-phosphorylase forms in cotyledons of Pisum sativum L.: Localization, developmental change, in-vitro translation, and processing. Planta 1991, 185, 432-439. [CrossRef] 
53. Satoh, H.; Shibahara, K.; Tokunaga, T.; Nishi, A.; Tasaki, M.; Hwang, S.-K.; Okita, T.W.; Kaneko, N.; Fujita, N.; Yoshida, M.; et al. Mutation of the plastidial alpha-glucan phosphorylase gene in rice affects the synthesis and structure of starch in the endosperm. Plant Cell 2008, 20, 1833-1849. [CrossRef]

54. Hwang, S.-K.; Singh, S.; Cakir, B.; Satoh, H.; Okita, T.W. The plastidial starch phosphorylase from rice endosperm: Catalytic properties at low temperature. Planta 2016, 243, 999-1009. [CrossRef] [PubMed]

55. Lee, S.-K.; Eom, J.-S.; Hwang, S.-K.; Shin, D.; An, G.; Okita, T.W.; Jeon, J.-S. Plastidic phosphoglucomutase and ADP-glucose pyrophosphorylase mutants impair starch synthesis in rice pollen grains and cause male sterility. J. Exp. Bot. 2016, 67, 5557-5569. [CrossRef]

56. Ritte, G.; Lloyd, J.R.; Eckermann, N.; Rottmann, A.; Kossmann, J.; Steup, M. The starch-related R1 protein is an $\alpha$-glucan, water dikinase. Proc. Natl. Acad. Sci. USA 2002, 99, 7166. [CrossRef]

57. Mikkelsen, R.; Baunsgaard, L.; Blennow, A. Functional characterization of alpha-glucan, water dikinase, the starch phosphorylating enzyme. Biochem. J. 2004, 377, 525-532. [CrossRef]

58. Kötting, O.; Pusch, K.; Tiessen, A.; Geigenberger, P.; Steup, M.; Ritte, G. Identification of a novel enzyme required for starch metabolism in Arabidopsis leaves. The phosphoglucan, Water Dikinase. Plant Physiol. 2005, 137, 242. [CrossRef]

59. Baunsgaard, L.; Lütken, H.; Mikkelsen, R.; Glaring, M.A.; Pham, T.T.; Blennow, A. A novel isoform of glucan, water dikinase phosphorylates pre-phosphorylated $\alpha$-glucans and is involved in starch degradation in Arabidopsis. Plant J. 2005, 41, 595-605. [CrossRef] [PubMed]

60. Blennow, A.; Engelsen, S.B. Helix-breaking news: Fighting crystalline starch energy deposits in the cell. Trends Plant Sci. 2010, 15, 236-240. [CrossRef] [PubMed]

61. Tagliabracci, V.S.; Roach, P.J. Insights into the mechanism of polysaccharide dephosphorylation by a glucan phosphatase. Proc. Natl. Acad. Sci. USA 2010, 107, 15312-15313. [CrossRef]

62. Reimann, R.; Ritte, G.; Steup, M.; Appenroth, K.-J. Association of $\alpha$-amylase and the R1 protein with starch granules precedes the initiation of net starch degradation in turions of Spirodela polyrhiza. Physiol. Plant 2002, 114, 2-12. [CrossRef]

63. Hirose, T.; Aoki, N.; Harada, Y.; Okamura, M.; Hashida, Y.; Ohsugi, R.; Miyao, A.; Hirochika, H.; Terao, T. Disruption of a rice gene for $\alpha$-glucan water dikinase, OsGWD1, leads to hyperaccumulation of starch in leaves but exhibits limited effects on growth. Front. Plant Sci. 2013, 4, 147. [CrossRef] [PubMed]

64. Chen, Y.; Sun, X.; Zhou, X.; Hebelstrup, K.H.; Blennow, A.; Bao, J. Highly phosphorylated functionalized rice starch produced by transgenic rice expressing the potato GWD1 gene. Sci. Rep. 2017, 7, 3339. [CrossRef]

65. Huang, L.-F.; Liu, Y.-K.; Su, S.-C.; Lai, C.-C.; Wu, C.-R.; Chao, T.-J.; Yang, Y.-H. Genetic engineering of transitory starch accumulation by knockdown of OsSEX4 in rice plants for enhanced bioethanol production. Biotechnol. Bioeng. 2020, 117, 933-944. [CrossRef]

66. Critchley, J.H.; Zeeman, S.C.; Takaha, T.; Smith, A.M.; Smith, S.M. A critical role for disproportionating enzyme in starch breakdown is revealed by a knock-out mutation in Arabidopsis. Plant. J. 2001, 26, 89-100. [CrossRef]

67. Blennow, A.; Nielsen, T.H.; Baunsgaard, L.; Mikkelsen, R.; Engelsen, S.B. Starch phosphorylation: A new front line in starch research. Trends Plant Sci. 2002, 7, 445-450. [CrossRef]

68. Kötting, O.; Santelia, D.; Edner, C.; Eicke, S.; Marthaler, T.; Gentry, M.S.; Comparot-Moss, S.; Chen, J.; Smith, A.M.; Steup, M.; et al. Starch-Excess4 is a laforin-like phosphoglucan phosphatase required for starch degradation in Arabidopsis thaliana. Plant Cell 2009, 21, 334-346. [CrossRef] [PubMed]

69. Santelia, D.; Kötting, O.; Seung, D.; Schubert, M.; Thalmann, M.; Bischof, S.; Meekins, D.A.; Lutz, A.; Patron, N.; Gentry, M.S.; et al. The phosphoglucan phosphatase like sex four2 dephosphorylates starch at the C3-position in Arabidopsis. Plant Cell 2011, 23, 4096-4111. [CrossRef] [PubMed]

70. Zeeman, S.C.; Rees, T.A. Changes in carbohydrate metabolism and assimilate export in starch-excess mutants of Arabidopsis. Plant Cell Environ. 1999, 22, 1445-1453. [CrossRef]

71. Ma, J.; Jiang, Q.-T.; Wei, L.; Yang, Q.; Zhang, X.-W.; Peng, Y.-Y.; Chen, G.-Y.; Wei, Y.-M.; Liu, C.; Zheng, Y.-L. Conserved structure and varied expression reveal key roles of phosphoglucan phosphatase gene starch excess 4 in barley. Planta 2014, 240, 1179-1190. [CrossRef] [PubMed]

72. Akdogan, G.; Kubota, J.; Kubo, A.; Takaha, T.; Kitamura, S. Expression and characterization of rice disproportionating enzymes. J. Appl. Glycosci. 2011, 58, 99-105. [CrossRef]

73. Dong, X.; Zhang, D.; Liu, J.; Liu, Q.Q.; Liu, H.; Tian, L.; Jiang, L.; Qu, L.Q. Plastidial disproportionating enzyme participates in starch synthesis in rice endosperm by transferring maltooligosyl groups from amylose and amylopectin to amylopectin. Plant Physiol. 2015, 169, 2496. [CrossRef] [PubMed]

74. Chia, T.; Thorneycroft, D.; Chapple, A.; Messerli, G.; Chen, J.; Zeeman, S.C.; Smith, S.M.; Smith, A.M. A cytosolic glucosyltransferase is required for conversion of starch to sucrose in Arabidopsis leaves at night. Plant J. 2004, 37, 853-863. [CrossRef] [PubMed]

75. Seung, D.; Smith, A.M. Starch granule initiation and morphogenesis_Progress in Arabidopsis and cereals. J. Exp. Bot. 2019, 70, 771-784. [CrossRef]

76. Seung, D. Amylose in starch: Towards an understanding of biosynthesis, structure and function. New Phytol. 2020, 228, 1490-1504. [CrossRef] 
77. Lohmeier-Vogel, E.M.; Kerk, D.; Nimick, M.; Wrobel, S.; Vickerman, L.; Muench, D.G.; Moorhead, G.B.G. Arabidopsis At5g39790 encodes a chloroplast-localized, carbohydrate-binding, coiled-coil domain-containing putative scaffold protein. BMC Plant Biol. 2008, 8, 120. [CrossRef]

78. Seung, D.; Soyk, S.; Coiro, M.; Maier, B.A.; Eicke, S.; Zeeman, S.C. Protein targeting to starch is required for localising granulebound starch synthase to starch granules and for normal amylose synthesis in Arabidopsis. PLoS Biol. 2015, 13, e1002080. [CrossRef]

79. Seung, D.; Echevarría-Poza, A.; Steuernagel, B.; Smith, A.M. Natural polymorphisms in Arabidopsis result in wide variation or loss of the amylose component of starch. Plant Physiol. 2020, 182, 870. [CrossRef] [PubMed]

80. Seung, D.; Boudet, J.; Monroe, J.; Schreier, T.B.; David, L.C.; Abt, M.; Lu, K.-J.; Zanella, M.; Zeeman, S.C. Homologs of Protein Targeting to Starch control starch granule initiation in Arabidopsis leaves. Plant Cell 2017, 29, 1657. [CrossRef]

81. Seung, D.; Schreier, T.B.; Bürgy, L.; Eicke, S.; Zeeman, S.C. Two plastidial coiled-coil proteins are essential for normal starch granule initiation in Arabidopsis. Plant Cell 2018, 30, 1523. [CrossRef]

82. Wang, W.; Wei, X.; Jiao, G.; Chen, W.; Wu, Y.; Sheng, Z.; Hu, S.; Xie, L.; Wang, J.; Tang, S.; et al. Gbss-Binding Protein, encoding a CBM48 domain-containing protein, affects rice quality and yield. J. Integr. Plant Biol. 2020, 62, 948-966. [CrossRef]

83. Peng, C.; Wang, Y.; Liu, F.; Ren, Y.; Zhou, K.; Lv, J.; Zheng, M.; Zhao, S.; Zhang, L.; Wang, C.; et al. Floury Endosperm6 encodes a CBM48 domain-containing protein involved in compound granule formation and starch synthesis in rice endosperm. Plant $\mathrm{J}$. 2014, 77, 917-930. [CrossRef] [PubMed]

84. Walsh, C.T.; Garneau-Tsodikova, S.; Gatto Jr, G.J. Protein posttranslational modifications: The chemistry of proteome diversifications. Angew. Chem. Int. Ed. 2005, 44, 7342-7372. [CrossRef] [PubMed]

85. Sreedhar, A.; Wiese, E.K.; Hitosugi, T. Enzymatic and metabolic regulation of lysine succinylation. Genes Dis. 2020, 7, 166-171. [CrossRef]

86. Ishimaru, T.; Matsuda, T.; Ohsugi, R.; Yamagishi, T. Morphological development of rice caryopses located at the different positions in a panicle from early to middle stage of grain filling. Funct Plant Biol. 2003, 30, 1139-1149. [CrossRef] [PubMed]

87. Zhang, Z.; Zhao, H.; Tang, J.; Li, Z.; Li, Z.; Chen, D.; Lin, W. A proteomic study on molecular mechanism of poor grain-filling of rice (Oryza sativa L.) inferior spikelets. PLoS ONE 2014, 9, e89140. [CrossRef]

88. Zhang, Z.; Tang, J.; Du, T.; Zhao, H.; Li, Z.; Li, Z.; Lin, W. Mechanism of developmental stagnancy of rice inferior spikelets at early grain-filling stage as revealed by proteomic analysis. Plant Mol. Biol. Report. 2015, 33, 1844-1863. [CrossRef]

89. Liao, J.-L.; Zhou, H.-W.; Zhang, H.-Y.; Zhong, P.-A.; Huang, Y.-J. Comparative proteomic analysis of differentially expressed proteins in the early milky stage of rice grains during high temperature stress. J. Exp. Bot. 2014, 65, 655-671. [CrossRef]

90. Timabud, T.; Yin, X.; Pongdontri, P.; Komatsu, S. Gel-free/label-free proteomic analysis of developing rice grains under heat stress. J. Proteom. 2016, 133, 1-19. [CrossRef]

91. Li, H.; Chen, Z.; Hu, M.; Wang, Z.; Hua, H.; Yin, C.; Zeng, H. Different effects of night versus day high temperature on rice quality and accumulation profiling of rice grain proteins during grain filling. Plant Cell Rep. 2011, 30, 1641-1659. [CrossRef]

92. Kaneko, K.; Sasaki, M.; Kuribayashi, N.; Suzuki, H.; Sasuga, Y.; Shiraya, T.; Inomata, T.; Itoh, K.; Baslam, M.; Mitsui, T. Proteomic and glycomic characterization of rice chalky grains produced under moderate and high-temperature conditions in field system. Rice 2016, 9, 26. [CrossRef]

93. Ishimaru, T.; Horigane, A.K.; Ida, M.; Iwasawa, N.; San-oh, Y.A.; Nakazono, M.; Nishizawa, N.K.; Masumura, T.; Kondo, M.; Yoshida, M. Formation of grain chalkiness and changes in water distribution in developing rice caryopses grown under high-temperature stress. J. Cereal Sci. 2009, 50, 166-174. [CrossRef]

94. Lemeer, S.; Heck, A.J.R. The phosphoproteomics data explosion. Curr. Opin. Chem. Biol. 2009, 13, 414-420. [CrossRef] [PubMed]

95. Yang, P. Phosphoproteomics in Cereals. In Plant Phosphoproteomics: Methods and Protocols; Schulze, W.X., Ed.; Springer: New York, NY, USA, 2015; pp. 47-57.

96. Reinders, J.; Sickmann, A. State-of-the-art in phosphoproteomics. Proteomics 2005, 5, 4052-4061. [CrossRef] [PubMed]

97. Sugiyama, N.; Nakagami, H.; Mochida, K.; Daudi, A.; Tomita, M.; Shirasu, K.; Ishihama, Y. Large-scale phosphorylation mapping reveals the extent of tyrosine phosphorylation in Arabidopsis. Mol. Syst. Biol. 2008, 4, 193. [CrossRef]

98. Adams, J.A. Kinetic and catalytic mechanisms of protein kinases. Chem. Rev. 2001, 101, 2271-2290. [CrossRef]

99. Fang, Y.; Deng, X.; Lu, X.; Zheng, J.; Jiang, H.; Rao, Y.; Zeng, D.; Hu, J.; Zhang, X.; Xue, D. Differential phosphoproteome study of the response to cadmium stress in rice. Ecotoxicol. Environ. Saf. 2019, 180, 780-788. [CrossRef]

100. Ye, J.; Zhang, Z.; Long, H.; Zhang, Z.; Hong, Y.; Zhang, X.; You, C.; Liang, W.; Ma, H.; Lu, P. Proteomic and phosphoproteomic analyses reveal extensive phosphorylation of regulatory proteins in developing rice anthers. Plant. J. 2015, 84, 527-544. [CrossRef]

101. Wang, Y.; Tong, X.; Qiu, J.; Li, Z.; Zhao, J.; Hou, Y.; Tang, L.; Zhang, J. A phosphoproteomic landscape of rice (Oryza sativa) tissues. Physiol. Plant. 2017, 160, 458-475. [CrossRef]

102. Sun, R.; Qin, S.; Zhang, T.; Wang, Z.; Li, H.; Li, Y.; Nie, Y. Comparative phosphoproteomic analysis of blast resistant and susceptible rice cultivars in response to salicylic acid. BMC Plant Biol. 2019, 19, 454. [CrossRef] [PubMed]

103. Han, C.; Yang, P.; Sakata, K.; Komatsu, S. Quantitative proteomics reveals the role of protein phosphorylation in rice embryos during early stages of germination. J. Proteome Res. 2014, 13, 1766-1782. [CrossRef] [PubMed]

104. Zhang, M.; Ma, C.-Y.; Lv, D.-W.; Zhen, S.-M.; Li, X.-H.; Yan, Y.-M. Comparative phosphoproteome analysis of the developing grains in bread wheat (Triticum aestivum L.) under well-watered and water-deficit conditions. J. Proteome Res. 2014, 13, 4281-4297. [CrossRef] 
105. Vu, L.D.; Zhu, T.; Verstraeten, I.; van de Cotte, B.; The International Wheat Genome Sequencing, C.; Gevaert, K.; De Smet, I. Temperature-induced changes in the wheat phosphoproteome reveal temperature-regulated interconversion of phosphoforms. J. Exp. Bot. 2018, 69, 4609-4624. [CrossRef] [PubMed]

106. Zhen, S.; Deng, X.; Zhang, M.; Zhu, G.; Lv, D.; Wang, Y.; Zhu, D.; Yan, Y. Comparative phosphoproteomic analysis under high-nitrogen fertilizer reveals central phosphoproteins promoting wheat grain starch and protein synthesis. Front. Plant. Sci. 2017, 8, 67. [CrossRef]

107. Chen, G.-X.; Zhou, J.-W.; Liu, Y.-L.; Lu, X.-B.; Han, C.-X.; Zhang, W.-Y.; Xu, Y.-H.; Yan, Y.-M. Biosynthesis and regulation of wheat amylose and amylopectin from proteomic and phosphoproteomic characterization of granule-binding proteins. Sci. Rep. 2016, 6, 33111. [CrossRef] [PubMed]

108. Lv, D.-W.; Zhu, G.-R.; Zhu, D.; Bian, Y.-W.; Liang, X.-N.; Cheng, Z.-W.; Deng, X.; Yan, Y.-M. Proteomic and phosphoproteomic analysis reveals the response and defense mechanism in leaves of diploid wheat T. monococcum under salt stress and recovery. $J$. Proteom. 2016, 143, 93-105. [CrossRef]

109. Ishikawa, S.; Barrero, J.M.; Takahashi, F.; Nakagami, H.; Peck, S.C.; Gubler, F.; Shinozaki, K.; Umezawa, T. Comparative phosphoproteomic analysis reveals a decay of ABA signaling in barley embryos during after-ripening. Plant Cell Physiol. 2019, 60, 2758-2768. [CrossRef]

110. Ishikawa, S.; Barrero, J.; Takahashi, F.; Peck, S.; Gubler, F.; Shinozaki, K.; Umezawa, T. Comparative phosphoproteomic analysis of Barley Embryos with different dormancy during imbibition. Int. J. Mol. Sci. 2019, 20, 451. [CrossRef]

111. Cao, H.; Zhou, Y.; Chang, Y.; Zhang, X.; Li, C.; Ren, D. Comparative phosphoproteomic analysis of developing maize seeds suggests a pivotal role for enolase in promoting starch synthesis. Plant Sci. 2019, 289, 110243. [CrossRef] [PubMed]

112. Zhao, X.; Bai, X.; Jiang, C.; Li, Z. Phosphoproteomic analysis of two contrasting maize inbred lines provides insights into the mechanism of salt-stress tolerance. Int. J. Mol. Sci. 2019, 20, 1886. [CrossRef]

113. Hu, X.; Wu, L.; Zhao, F.; Zhang, D.; Li, N.; Zhu, G.; Li, C.; Wang, W. Phosphoproteomic analysis of the response of maize leaves to drought, heat and their combination stress. Front. Plant Sci. 2015, 6, 298. [CrossRef]

114. Wu, L.; Wang, S.; Wu, J.; Han, Z.; Wang, R.; Wu, L.; Zhang, H.; Chen, Y.; Hu, X. Phosphoproteomic analysis of the resistant and susceptible genotypes of maize infected with sugarcane mosaic virus. Amino Acids 2015, 47, 483-496. [CrossRef]

115. Lu, T.C.; Meng, L.B.; Yang, C.P.; Liu, G.F.; Liu, G.J.; Ma, W.; Wang, B.C. A shotgun phosphoproteomics analysis of embryos in germinated maize seeds. Planta 2008, 228, 1029-1041. [CrossRef]

116. Nakagami, H.; Sugiyama, N.; Mochida, K.; Daudi, A.; Yoshida, Y.; Toyoda, T.; Tomita, M.; Ishihama, Y.; Shirasu, K. Large-scale comparative phosphoproteomics identifies conserved phosphorylation sites in plants. Plant Physiol. 2010, 153, 1161-1174. [CrossRef]

117. Tetlow, I.J.; Wait, R.; Lu, Z.; Akkasaeng, R.; Bowsher, C.G.; Esposito, S.; Kosar-Hashemi, B.; Morell, M.K.; Emes, M.J. Protein phosphorylation in amyloplasts regulates starch branching enzyme activity and protein-protein interactions. Plant Cell 2004, 16, 694-708. [CrossRef] [PubMed]

118. Liu, F.; Makhmoudova, A.; Lee, E.A.; Wait, R.; Emes, M.J.; Tetlow, I.J. The amylose extender mutant of maize conditions novel protein-protein interactions between starch biosynthetic enzymes in amyloplasts. J. Exp. Bot. 2009, 60, 4423-4440. [CrossRef]

119. Tetlow, I.J.; Beisel, K.G.; Cameron, S.; Makhmoudova, A.; Liu, F.; Bresolin, N.S.; Wait, R.; Morell, M.K.; Emes, M.J. Analysis of protein complexes in wheat amyloplasts reveals functional interactions among starch biosynthetic enzymes. Plant Physiol. 2008, 146, 1878. [CrossRef] [PubMed]

120. Mehrpouyan, S.; Menon, U.; Tetlow, I.J.; Emes, M.J. Protein phosphorylation regulates maize endosperm starch synthase IIa activity and protein-protein interactions. Plant J. 2021, 105, 1098-1112. [CrossRef]

121. Liu, F.; Ahmed, Z.; Lee, E.A.; Donner, E.; Liu, Q.; Ahmed, R.; Morell, M.K.; Emes, M.J.; Tetlow, I.J. Allelic variants of the amylose extender mutation of maize demonstrate phenotypic variation in starch structure resulting from modified protein-protein interactions. J. Exp. Bot. 2012, 63, 1167-1183. [CrossRef] [PubMed]

122. Ahmed, Z.; Tetlow, I.J.; Ahmed, R.; Morell, M.K.; Emes, M.J. Protein-protein interactions among enzymes of starch biosynthesis in high-amylose barley genotypes reveal differential roles of heteromeric enzyme complexes in the synthesis of A and B granules. Plant Sci. 2015, 233, 95-106. [CrossRef]

123. Liu, D.-R.; Huang, W.-X.; Cai, X.-L. Oligomerization of rice granule-bound starch synthase 1 modulates its activity regulation. Plant Sci. 2013, 210, 141-150. [CrossRef]

124. Wang, S.J.; Liu, L.F.; Chen, C.K.; Chen, L.W. Regulations of granule-bound starch synthase I gene expression in rice leaves by temperature and drought stress. Biol. Plant. 2006, 50, 537-541. [CrossRef]

125. Crofts, N.; Abe, N.; Oitome, N.F.; Matsushima, R.; Hayashi, M.; Tetlow, I.J.; Emes, M.J.; Nakamura, Y.; Fujita, N. Amylopectin biosynthetic enzymes from developing rice seed form enzymatically active protein complexes. J. Exp. Bot. 2015, 66, 4469-4482. [CrossRef]

126. Crofts, N.; Iizuka, Y.; Abe, N.; Miura, S.; Kikuchi, K.; Matsushima, R.; Fujita, N. Rice mutants lacking Starch Synthase I or Branching Enzyme IIb activity altered starch biosynthetic protein complexes. Front. Plant Sci. 2018, 9, 1817. [CrossRef]

127. Chen, Y.; Pang, Y.; Bao, J.S. Expression profiles and protein complexes of starch biosynthetic enzymes from white-core and waxy mutants induced from high amylose Indica rice. Rice Sci. 2020, 27, 152-161. [CrossRef] 
128. Hwang, S.-K.; Koper, K.; Satoh, H.; Okita, T.W. Rice endosperm starch phosphorylase (Pho1) assembles with disproportionating enzyme (Dpe1) to form a protein complex that enhances synthesis of malto-oligosaccharides. J. Biol. Chem. 2016, 291, 19994-20007. [CrossRef]

129. Liu, Z.; Cao, J.; Gao, X.; Zhou, Y.; Wen, L.; Yang, X.; Yao, X.; Ren, J.; Xue, Y. CPLA 1.0: An integrated database of protein lysine acetylation. Nucleic Acids Res. 2011, 39, D1029-D1034. [CrossRef]

130. Choudhary, C.; Kumar, C.; Gnad, F.; Nielsen, M.L.; Rehman, M.; Walther, T.C.; Olsen, J.V.; Mann, M. Lysine acetylation targets protein complexes and co-regulates major cellular functions. Science 2009, 325, 834. [CrossRef]

131. Nallamilli, B.R.R.; Edelmann, M.J.; Zhong, X.; Tan, F.; Mujahid, H.; Zhang, J.; Nanduri, B.; Peng, Z. Global analysis of lysine acetylation suggests the involvement of protein acetylation in diverse biological processes in rice (Oryza sativa). PLoS ONE 2014, 9, e89283. [CrossRef]

132. Wang, Q.; Zhang, Y.; Yang, C.; Xiong, H.; Lin, Y.; Yao, J.; Li, H.; Xie, L.; Zhao, W.; Yao, Y.; et al. Acetylation of metabolic enzymes coordinates carbon source utilization and metabolic flux. Science 2010, 327, 1004-1007. [CrossRef]

133. Glozak, M.A.; Sengupta, N.; Zhang, X.; Seto, E. Acetylation and deacetylation of non-histone proteins. Gene 2005, 363, 15-23. [CrossRef]

134. Yan, Z.; Shen, Z.; Gao, Z.-F.; Chao, Q.; Qian, C.-R.; Zheng, H.; Wang, B.-C. A comprehensive analysis of the lysine acetylome reveals diverse functions of acetylated proteins during de-etiolation in Zea mays. J. Plant Physiol. 2020, 248, 153158. [CrossRef]

135. Zhen, S.; Deng, X.; Wang, J.; Zhu, G.; Cao, H.; Yuan, L.; Yan, Y. First comprehensive proteome analyses of lysine acetylation and succinylation in seedling leaves of Brachypodium distachyon L. Sci. Rep. 2016, 6, 31576. [CrossRef]

136. Zhang, Z.; Tan, M.; Xie, Z.; Dai, L.; Chen, Y.; Zhao, Y. Identification of lysine succinylation as a new post-translational modification. Nat. Chem. Biol. 2011, 7, 58-63. [CrossRef]

137. Xie, Z.; Dai, J.; Dai, L.; Tan, M.; Cheng, Z.; Wu, Y.; Boeke, J.D.; Zhao, Y. Lysine succinylation and lysine malonylation in histones. Mol. Cell. Proteom.: MCP 2012, 11, 100-107. [CrossRef]

138. Xu, H.; Chen, X.; Xu, X.; Shi, R.; Suo, S.; Cheng, K.; Zheng, Z.; Wang, M.; Wang, L.; Zhao, Y.; et al. Lysine acetylation and succinylation in HeLa Cells and their essential roles in response to UV-induced Stress. Sci. Rep. 2016, 6, 30212. [CrossRef]

139. Wang, C.; Zhang, C.; Li, X.; Shen, J.; Xu, Y.; Shi, H.; Mu, X.; Pan, J.; Zhao, T.; Li, M.; et al. CPT1A-mediated succinylation of S100A10 increases human gastric cancer invasion. J. Cell Mol. Med. 2019, 23, 293-305. [CrossRef]

140. Kidwai, S.A.; Ansari, A.A.; Salahuddin, A. Effect of succinylation (3-carboxypropionylation) on the conformation and immunological activity of ovalbumin. Biochem. J. 1976, 155, 171-180. [CrossRef]

141. Kurmi, K.; Hitosugi, S.; Wiese, E.K.; Boakye-Agyeman, F.; Gonsalves, W.I.; Lou, Z.; Karnitz, L.M.; Goetz, M.P.; Hitosugi, T. Carnitine Palmitoyltransferase 1A has a lysine succinyltransferase activity. Cell Rep. 2018, 22, 1365-1373. [CrossRef]

142. Jin, W.; Wu, F. Proteome-wide identification of lysine succinylation in the proteins of tomato (Solanum lycopersicum). PLoS ONE 2016, 11, e0147586. [CrossRef] [PubMed]

143. Wang, X.; Chen, X.; Li, J.; Zhou, X.; Liu, Y.; Zhong, L.; Tang, Y.; Zheng, H.; Liu, J.; Zhan, R.; et al. Global analysis of lysine succinylation in patchouli plant leaves. Hortic. Res. 2019, 6, 133. [CrossRef] [PubMed]

144. Qiu, C.; Wang, Y.; Sun, J.H.; Qian, W.J.; Xie, H.; Ding, Y.Q.; Ding, Z.T. A qualitative proteome-wide lysine succinylation profiling of tea revealed its involvement in primary metabolism. Mol. Biol. 2020, 54, 144-155. [CrossRef]

145. Dai, L.; Peng, C.; Montellier, E.; Lu, Z.; Chen, Y.; Ishii, H.; Debernardi, A.; Buchou, T.; Rousseaux, S.; Jin, F.; et al. Lysine 2-hydroxyisobutyrylation is a widely distributed active histone mark. Nat. Chem. Biol. 2014, 10, 365-370. [CrossRef]

146. Hirschey, M.D.; Zhao, Y. Metabolic regulation by lysine malonylation, succinylation, and glutarylation. Mol. Cell. Proteom. MCP 2015, 14, 2308-2315. [CrossRef] [PubMed]

147. Peng, C.; Lu, Z.; Xie, Z.; Cheng, Z.; Chen, Y.; Tan, M.; Luo, H.; Zhang, Y.; He, W.; Yang, K.; et al. The first identification of lysine malonylation substrates and its regulatory enzyme. Mol. Cell Proteom. 2011, 10, M111.012658. [CrossRef]

148. Huang, H.; Tang, S.; Ji, M.; Tang, Z.; Shimada, M.; Liu, X.; Qi, S.; Locasale, J.W.; Roeder, R.G.; Zhao, Y.; et al. p300-dediated lysine 2-hydroxyisobutyrylation regulates glycolysis. Mol. Cell 2018, 70, 663-678.e666. [CrossRef]

149. Chen, X.; Li, X.; Li, P.; Chen, X.; Liu, H.; Huang, J.; Luo, C.; Hsiang, T.; Zheng, L. Comprehensive identification of lysine 2-hydroxyisobutyrylated proteins in Ustilaginoidea virens reveals the involvement of lysine 2-hydroxyisobutyrylation in fungal virulence. J. Integr. Plant. Biol. 2021, 63, 409-425. [CrossRef]

150. Du, Y.; Cai, T.; Li, T.; Xue, P.; Zhou, B.; He, X.; Wei, P.; Liu, P.; Yang, F.; Wei, T. Lysine malonylation is elevated in type 2 diabetic mouse models and enriched in metabolic associated proteins. Mol. Cell. Proteom. MCP 2015, 14, 227-236. [CrossRef]

151. Galván-Peña, S.; Carroll, R.G.; Newman, C.; Hinchy, E.C.; Palsson-McDermott, E.; Robinson, E.K.; Covarrubias, S.; Nadin, A.; James, A.M.; Haneklaus, M.; et al. Malonylation of GAPDH is an inflammatory signal in macrophages. Nat. Commun. 2019, 10, 338. [CrossRef]

152. Colak, G.; Pougovkina, O.; Dai, L.; Tan, M.; Te Brinke, H.; Huang, H.; Cheng, Z.; Park, J.; Wan, X.; Liu, X.; et al. Proteomic and biochemical studies of lysine malonylation suggest its malonic aciduria-associated regulatory role in mitochondrial function and fatty acid oxidation. Mol. Cell. Proteom. MCP 2015, 14, 3056-3071. [CrossRef] [PubMed] 